Sharif University of Technology
Scientia Iranica
TCIENTIA
I RAN ICA
http://scientiairanica.sharif.edu

\title{
Water flow stabilization using submerged weir for draft-tube reaction hydraulic turbine
}

\author{
A.M. Salih Ameen ${ }^{\mathrm{a}, *}$, Z. Ibrahim ${ }^{\mathrm{a}}$, F. Othman ${ }^{\mathrm{a}}$, and Z. Mundher Yaseen ${ }^{\mathrm{b}, *}$ \\ a. Department of Civil Engineering, Faculty of Engineering, University of Malaya, 50603 Kuala Lumpur, Malaysia. \\ b. Sustainable Developments in Civil Engineering Research Group, Faculty of Civil Engineering, Ton Duc Thang University, Ho \\ Chi Minh City, Vietnam.
}

Received 17 December 2017; received in revised form 20 January 2018; accepted 29 April 2018

\author{
KEYWORDS \\ Numerical fluid \\ analysis; \\ Hydropower \\ sustainability; \\ Water pressure and \\ velocity; \\ Submerged weir; \\ Reaction turbine.
}

\begin{abstract}
In turbine engineering, draft-tube downstream runs under extreme water flow pressure and velocity, causing vibration and pressure variation in different operation frequencies. The practical challenge of obtaining stabilized water flow is an ongoing domain of research. This paper investigates a proposition of applying a submerged weir at the downstream end of the draft-tube reaction turbine. The main goal of this research is to reduce variations in water flow pressure, velocity, and shear distribution in accordance with the effect of the upstream water level. Two types of turbines, including vertical Kaplan and Francis turbine units, are examined. ANSYS CFX software tool is used to build threedimensionally (3D) numerical models for the Kaplan and Francis turbines by building a submerged weir at the outlet of the draft tubes based on three different height suggestions. The effect of the proposed submerged weir on the flow through these turbines is studied by considering the dimensions of their components including the penstock with inlets, spiral casing, shafts and blades, and the draft tube with outlets. The findings of this research are significant enough to solve the problem of negative pressure pulsation in the draft tube of Kaplan and Francis turbines types.
\end{abstract}

(C) 2020 Sharif University of Technology. All rights reserved.

\section{Introduction}

Powerhouses are among the main parts of dams that are used to generate low-cost hydroelectric power. The hydraulic characteristics of Kaplan and Francis turbine units [1] are identified that function as the main engine of a powerhouse. Kaplan and Francis turbines, which are classified as reaction turbines, are difficult to use under part-load operation because of pressure oscillation [2-4]. Studies on this topic have

*. Corresponding authors. Tel.: 00601125112953

E-mail addresses: ameenmsalih@siswa.um.edu.my (A.M. Salih Ameen); yaseen@tdtu.edu.vn (Z. Mundher Yaseen)

doi: $10.24200 /$ sci. 2018.50038 .1476 presented solutions for the cavitation problem in draft tubes [5], the vibration effect in powerhouses caused by a running turbine, maximization of power generation, and generation of low-cost power $[1,6]$.

Over the last decade, there has been a very noticeable development in the computational fluid tools [7$9]$. It has become very effective in performing a robust and reliable analysis of the flow pattern phenomenon inside the turbine structure. Based on the literature, numerous studies have been conducted by utilizing the aforementioned tools to simulate the flow behavior in the draft tube of a turbine and inspect the critical condition such as vortex rope and vibration $[2,10]$. Researchers have studied pressure pulsation in Francis hydraulic turbine units and discussed the cavitation phenomenon problem [11,12]. Jošt and Lipej (2011) 
built a 3D numerical model for a Francis turbine unit to predict vortex rope in the draft tube based on numerical flow analyses [13]. Two analyses with and without cavitation effects were performed. Another study performed a numerical analysis of cavitation turbulent flow in a Francis turbine under partial load operation using the $k-\omega$ shear stress transport turbulence model in Reynolds-averaged Navier-Stokes equations [14]. Qian et al. (2007) simulated 3D multiphase flow in a Francis turbine to calculate pressure pulsation in the spiral casing, draft tube, runner front, and guide vanes using fast Fourier transform [15]. The investigation of the hydrodynamic effects of pressure fluctuation in the draft tube was studied [16]. The cause of the simulated rotor-stator interaction under partial load operation was investigated by analyzing the 3D transient-state turbulence flow simulation of a Francis tube. The 3D Navier-Stokes Computational Fluid Dynamics (CFD) solver ANSYS CFX was used to analyze flow through a vertical Francis turbine with different loads in situ. Lately, Luna-Ramírez et al. (2016) calculated pressure on the blades of a $200 \mathrm{MW}$ Francis hydraulic turbine to locate failure on the blade surface based on CFD [17]. Recently, an attempt has been made to investigate the local wave speed and bulk flow viscosity in Francis turbine [18]. Moreover, several studies conducted the Francis turbine analysis through the advantages of computational features [19-23].

Other researchers have discussed pressure pulsation in Kaplan hydraulic turbine units and presented methods to reduce the cavitation problem. Ko and Kurosawa (2014) evaluated and presented cavitation performance at a specific speed for a 400 MW Kaplan turbine using a finite volume method to solve the Reynolds-averaged Navier-Stokes equations combined with the Reynolds stress model [24]. The modified Rayleigh-Plesset equation was used to model the collapse and growth of cavitation bubbles. Javadi and Nilsson (2014) adopted the renormalization group $k-\varepsilon$ turbulence model combined with the Reynoldsaveraged Navier-Stokes equations to analyze unsteady turbulent flow in a U9 Kaplan turbine model [25]. Analyses were performed on the fluctuation of pressure in the draft tube, unsteady flow behavior, and cohesive flow structures. Another investigation was carried out on the runner outlet flow of a Francis turbine model using a two-component particle image velocimetry system [26]. The finding of the research proposed a particular shape that provides suitable optical access across the draft tube elbow. The characteristics of the flow pattern in a Francis turbine runner with a small opening valve using the Reynolds-averaged Navier-Stokes equations and the continuity equation were inspected [27]. The 3D unsteady turbulence flow throughout the entire passage of the turbine was simulated numerically based on the $k-\varepsilon$ two- equation turbulence model using the CFD software ANSYS Fluent. The finding of the study showed that a low-pressure zone expanded around the blades of the runner when the valve was closed, and velocity increased throughout the runner area. On the other hand, the effect of hydraulic instabilities on increasing the service lifetime of Francis and Kaplan turbines was accomplished [1]. In particular, Caishui (2012 built a mathematical model to study pressure distribution in the flow pattern inside the powerhouse of a hydropower station using a fluid dynamics method (CFD) to determine the velocity distribution and pressure pattern distribution under three operating conditions: one-unit load, two-unit load, and full-load rejection [28]. The results of this study outlined good flow patterns at the inlet with steady water level fluctuations. Many state-of-the-art studies on the pressure pulsation in the draft tube of Kaplan and Francis turbines rely on the same methods and analyses, yet use different models. Based on a comprehensive review of the article published [2], several researchers have suggested changes in turbine design to reduce the cavitation phenomenon and increase turbine efficiency.

In the current work and to the best knowledge of the authors, construction of a submerged weir with three different heights (i.e., $1 / 6,1 / 3$, and $1 / 2$ from the draft-tube outlet height) was suggested to decrease the pressure variation in the draft tubes of turbine units. The main enthusiasm for establishing this research results from the main concept of broadcrested weir that stabilizes the flow through the open channel $[29,30]$. Two reaction hydraulic turbines in two different embankment dams are selected as a real practical example to evaluate hydraulic performance. The hydraulic performances include pressure stability in the draft tubes of a vertical Kaplan turbine used in the Haditha Power Station and a vertical Francis turbine used in the Temenggor Power Station. A 3D numerical model with one turbine unit for each powerhouse is analyzed and simulated using ANSYS CFX software tool at different water levels (minimum to maximum). The discharge and hydraulic information was obtained from sites. Flow velocity, pressure distribution, and shear wall distribution were determined in different loading cases using the $k-\varepsilon$ turbulence model. The finite volume method was adopted, and the physical properties and flow characteristics of water were defined. The simulation results of the models determined the characteristics of the turbines obtained by running the $3 \mathrm{D}$ turbine models, which are changeable with respect to the upstream and downstream water levels and discharge ranges. This study provides a foundation for determining the hydraulic characteristic performance of reaction turbines to compare the two types of hydropower station: The Haditha powerhouse, which is an integral part of the dam body, and the 
Temenggor powerhouse, which is separate from the dam body. A safe and low-cost method for generating hydroelectric power can be identified.

\section{Dams and power stations description}

\subsection{Haditha Dam}

The Haditha Dam is an earth-fill dam located on the Euphrates River, north of Haditha City, Iraq. This dam is over $9 \mathrm{~km}$ long and $57 \mathrm{~m}$ high. The Haditha Dam was built to generate hydroelectricity and regulate water for irrigation [31]. The power station in the Haditha Dam contains 6 vertical Kaplan turbines that can generate $660 \mathrm{MW}$ of electricity. Figure 1(a) outlines the downstream flow of the Haditha Dam with 6 outlets opening into the spillway, 12 outlets opening into the power station, and 2 outlets opening into each turbine unit. Full details of the hydraulic characteristics of the dam are tabulated in Table 1.

\subsection{Temenggor Dam}

The Temenggor Dam is the third largest dam in Malaysia, and the Temenggor Power Station is one of the largest hydroelectric power generation facilities in Malaysia. It is located in Sungai Perak, approximately $200 \mathrm{~km}$ northeast of Ipoh state [32]. This rock-fill dam has a height of $128 \mathrm{~m}$ and a crest length of $537 \mathrm{~m}$. The Temenggor Power Station has four vertical Francis turbines with an installed capacity of $348 \mathrm{MW}$; it is considered a separate powerhouse. Figure 1(b) illustrates the Temenggor Dam with eight outlets of the surface downstream power station. Table 1 presents the hydraulic information required to build the models for the turbine units.

\section{Methodology overview}

This reaction turbine represents one of the largest hydraulic structures. Water pressure applies force to

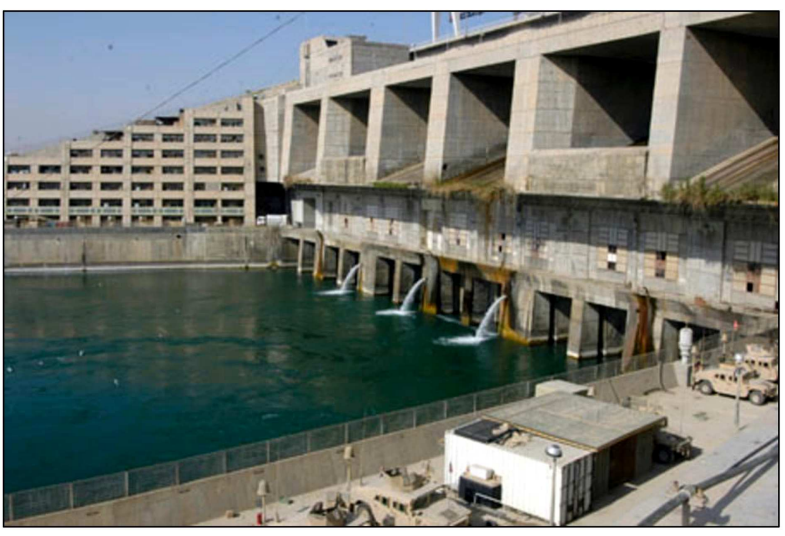

(a)

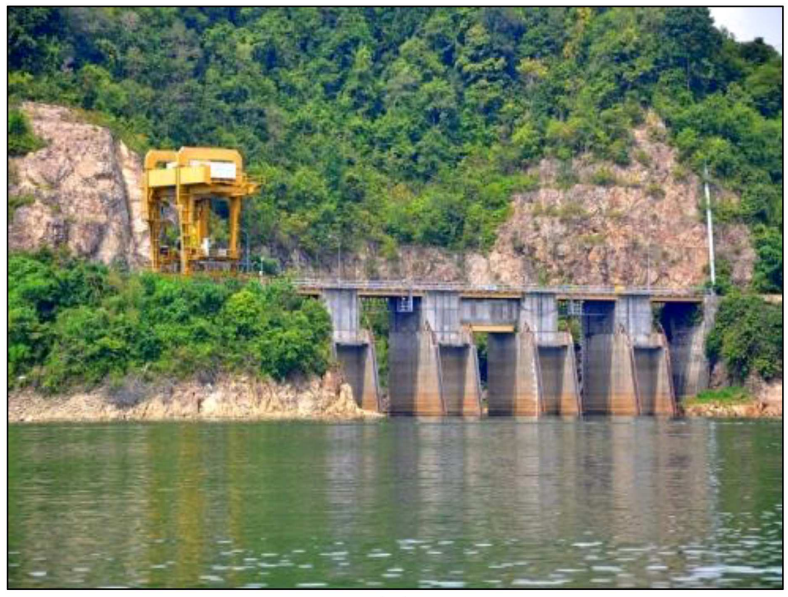

(b)

Figure 1. (a) Haditha Dam with spillway and power-station outlets. (b) Downstream of Temenggor Dam with outlets of the surface power station.

runner blades, and this pressure decreases throughout the running turbine; this phenomenon was observed in both Francis and Kaplan turbines. The runner and the blades of the turbines are fully immersed in water and must be sufficiently strong to resist the operating

Table 1. The hydraulic information of Hadith and Temenggor power stations.

\begin{tabular}{lcc}
\hline \multicolumn{1}{c}{ Properties } & Haditha Dam & Temenggor Dam \\
\hline Type of the dam & Earthfill & Rockfill \\
Location & $34^{\circ} 12^{\prime} 25^{\prime \prime} \mathrm{N}, 42^{\circ} 21^{\prime} 18^{\prime \prime} \mathrm{E}$ & $5^{\circ} 24^{\prime} 24^{\prime \prime} \mathrm{N}, 101^{\circ} 18^{\prime} 4^{\prime \prime} \mathrm{E}$ \\
Power house type & Integral part of dam body & Surface power house \\
Type of turbines & Vertical Kaplan & Vertical Francis \\
Number of units & 6 & 4 \\
Install capacity (MW) & $6 \times 110=600$ & $4 \times 87=348$ \\
Length of unit (m) & 67.35 & 260 \\
Penstock diameter $(\mathrm{m})$ & The details shown in Figure 2 & 5.5 \\
Maximum U/S.W. L $(\mathrm{m})$ & 150.2 & 248.42 \\
Minimum U/S.W. L $(\mathrm{m})$ & 129 & 236.5 \\
D/S.W. L (m) & 107.3 & 142 \\
Maximum power house discharge $\left(\mathrm{m}^{3} / \mathrm{s}\right)$ & $6 \times 339=2034$ & $4 \times 100=400$ \\
Spillway & Included dam body & Separated structure \\
Max. spillway discharge $\left(\mathrm{m}^{3} / \mathrm{s}\right)$ & 11000 & 2883 \\
\hline
\end{tabular}


pressure. The hydraulic power of the turbine units is given in Eq. (1) [33,34]:

$$
P=\rho \cdot Q \cdot g \cdot H \cdot \eta
$$

where $P$ is the water pressure, $\rho$ is the water mass density, $Q$ is the water discharge, $g$ is the gravity weight, $H$ is the water head, and $\eta$ is the efficiency.

The energy of turbines $E$ is defined as can be seen in Eq. (2) [35]:

$$
\begin{aligned}
E= & g \cdot H_{t}=\left(\frac{p_{1}-p_{2}}{\rho}\right)+\left(\frac{V_{1}^{2}-V_{2}^{2}}{2}\right)+g \cdot\left(z_{1}-z_{2}\right) \\
& + \text { head } \text { loss }_{1-2},
\end{aligned}
$$

where $H_{t}$ is the water head of the turbine. Sections 1 and 2 are defined as the upstream and downstream measurements of the turbine, respectively. The determined behavior of the hydraulic turbine models is based on a dimensional analysis. Laboratory developments and model tests can guarantee hydraulic behavior and turbine efficiency [36]. The International Electrotechnical Commission Standards 60193 and 60041 define all the simulation rules [37,38]. The specific speed of a turbine based on these standards is defined in the following formula [34,39]:

$$
n_{Q E}=\frac{n \cdot \sqrt{Q}}{\left(g H_{n}\right)^{3 / 4}} .
$$

Parameter $n_{Q E}$ is known as the specific speed of any type of turbines. Numerous statistical studies on reaction turbines have established a correlation between speed and net head for each type of turbine. The Schweiger and Gregory correlation formulas for Kaplan turbines are defined as follows [40]:

$$
\text { Kaplan } \quad n_{Q E}=\frac{2.294}{H_{n}^{0.486}} .
$$

The Lugaresi and Mass correlation formulas for Francis turbines are presented as follows [41]:

$$
\text { Francis } \quad n_{Q E}=\frac{1.924}{H_{n}^{0.512}} \text {. }
$$

The previous statistical formulas are used only for preliminary studies during the first trial to estimate the specific speed so as to set the rotational speed of a turbine by applying Eqs. (3), (4), and (5), because there exists no clear relationship among the head, flow rate, and the rotational speed of the turbine.

\section{3D numerical finite element turbine model}

In this study, two different kinds of turbines (e.g., Kaplan and Francis) are selected as case studies to investigate. ANSYS CFX is used to simulate the 3D numerical finite-volume flow turbine models including the runner with blades, and the shaft is defined as the submerged rotational body. The water field includes two rectangular inlets for the Kaplan turbine and one circular inlet for the Francis turbine. The penstock, the spiral casing, the draft tube, and two rectangular outlets are defined. The boundary conditions include the discharge range, the operating head, the rotational speed of the turbines, and the effect of gravity. The two models run with three submerged weirs are recommended to be applied to the downstream of turbine units. Figure 2(a) and (b) display the dimensions of the units.

The ANSYS-CFX software used for simulation relies on the finite-volume method. The first step of the calculation is study-state flow field, and the result of this step represents the initial condition for the next step. The flow simulation of the Francis turbine unit was employed by using several meshes to test grid independence. After many iterations, the calculations reach convergence.

The second step in turbine modeling involves the selection of a suitable finite volume mesh. The grid of the turbine is made of tetrahedral elements after performing several trials to determine the smallest possible aspect ratio under 150 and the minimum orthogonal over 0.15 in accordance with ANSYS-CFX code recommendations, whereas analysis of hexahedral elements was performed for the walls' boundary layers. The final mesh satisfies $y^{+}<200$ around the boundary wall to obtain the required pressure fluctuation, following the previous research conducted by [42]. The runner, guide vanes, and draft-tube interactions were evaluated by slip meshes. This mesh slipping was observed to be interacting on the sides of interface. However, it is important to ensure that velocity components, pressure, and flow flux are harmonious after interpolation. The meshing details used in the Haditha Kaplan turbine model and Temenggor Francis turbine are shown in Table 2. The number of elements and nodes used in Temenggor turbine meshing is higher than that in the Haditha turbine model, because the Temenggor turbine unit is longer than the Haditha turbine unit. The Francis runner with 12 blades has several fine details represented by small elements, whereas the Kaplan runner includes only 6 blades with details larger than those of the Temenggor runner turbine. The outlet boundary condition, the relative static pressure, turbulent kinetic energy, and its diffusion rate are prescribed; no-slip boundary condition is applied to the wall, and standard wall functions are applied to the region near the wall [43]. Figure 3 illustrates the examples of the meshing details for the two-component turbine model.

The water flow through the draft tube was mod- 


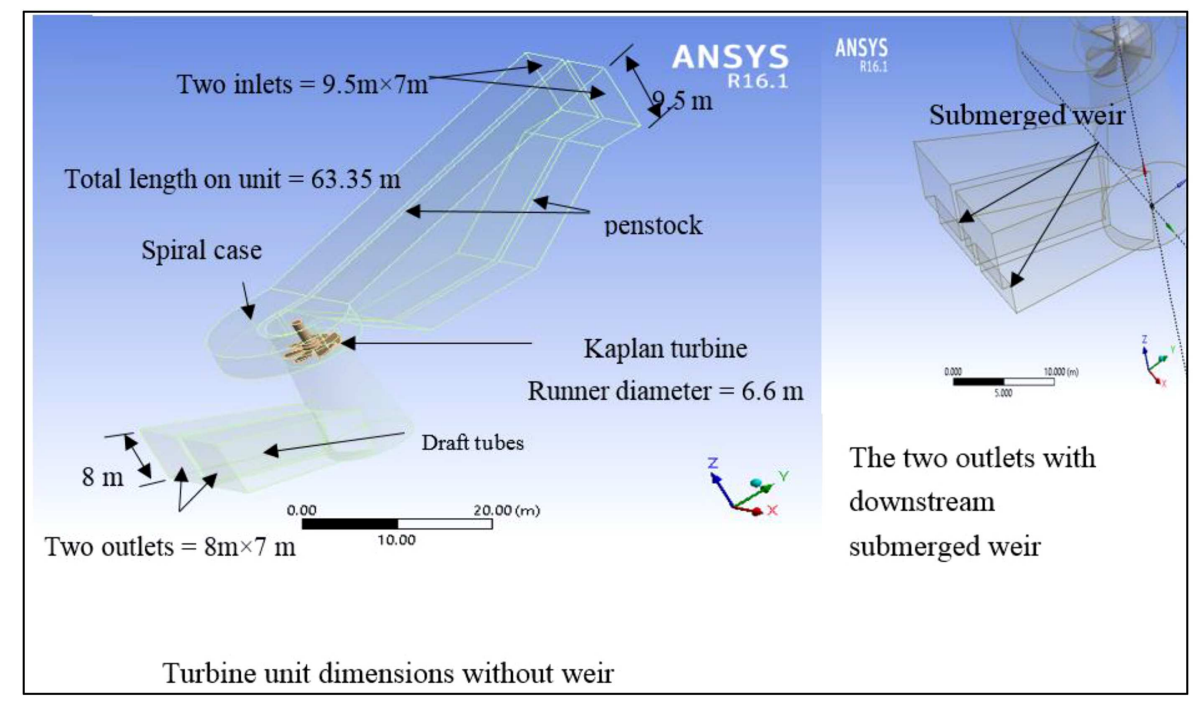

(a)

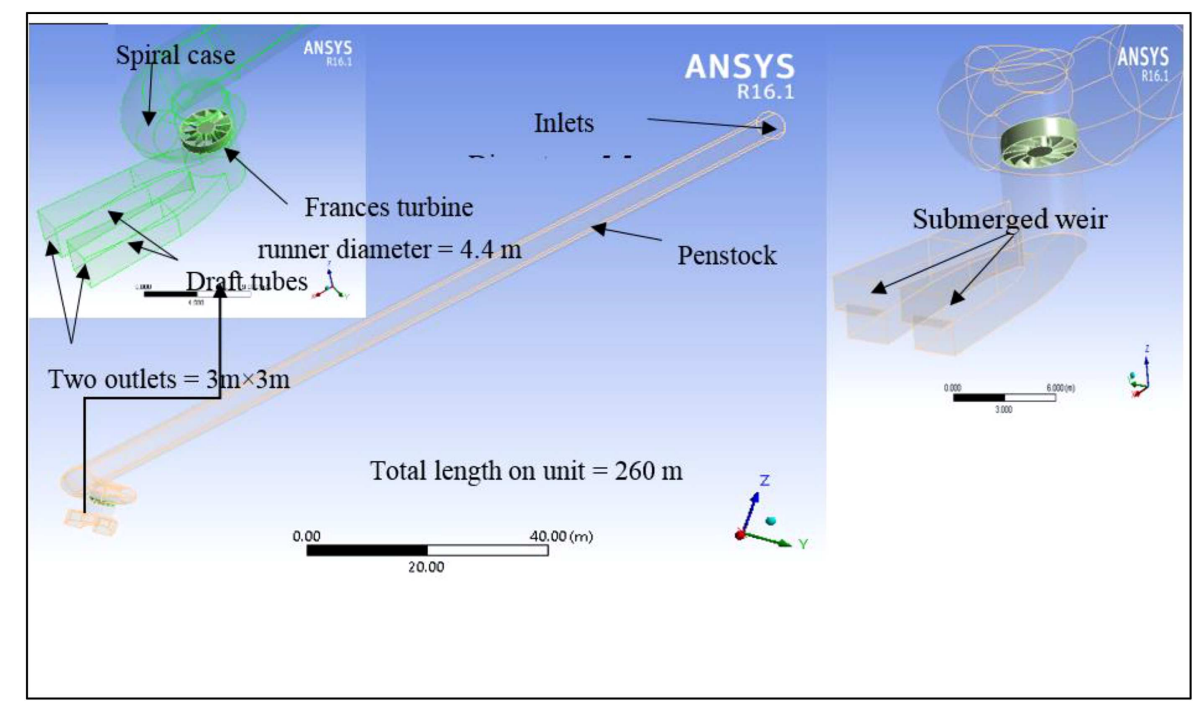

(b)

Figure 2. (a) 3D model of a vertical Kaplan unit with dimensions. (b) 3D model of a vertical Francis unit with dimensions.

eled using the incompressible continuity formulation and Reynolds time average. The mathematical explanation can be presented as follows [42]. The water flow continuity formula is:

$$
\frac{\partial u_{j}}{\partial x_{j}}=0
$$

In addition, the momentum formula is presented as follows:

$$
\rho \frac{\partial u_{i}}{\partial t}+\rho u_{j} \frac{\partial u_{i}}{\partial x_{j}}=\rho F_{i}-\frac{\partial P}{\partial x_{i}}+\mu \frac{\partial^{2} u_{i}}{\partial x_{j} \partial x_{i}}-\rho \frac{\partial\left(u_{i}^{\prime} u_{j}^{\prime}\right)}{\partial x_{j}}
$$

where:

$$
-\rho u_{i}^{\prime} u_{j}^{\prime}=\mu_{t}\left(\frac{\partial u_{i}}{\partial x_{j}}+\frac{\partial u_{j}}{\partial x_{i}}\right)-\frac{2}{3}\left(p k+\mu_{t} \frac{\partial u_{i}}{\partial x_{i}}\right) \delta_{i j} .
$$

The double formula of the $k-\varepsilon$ is:

$$
\begin{aligned}
\rho \frac{D k}{D t}= & \frac{\partial}{\partial x_{j}}\left(\alpha_{k} \mu_{e f f} \frac{\partial k}{\partial x_{j}}\right)+2 \mu_{t} S_{i j} \frac{\partial u_{i}}{\partial x_{j}}+\rho \varepsilon \\
\rho \frac{D k}{D t}= & \frac{\partial}{\partial x_{j}}\left(\alpha_{\varepsilon} \mu_{e f f} \frac{\partial k}{\partial x_{j}}\right)+2 C_{1 \varepsilon} \frac{\varepsilon}{k} v_{t} \delta_{i j} \frac{\partial u_{i}}{\partial x_{j}} \\
& -C_{2 \varepsilon} \frac{\varepsilon^{2}}{k}-R,
\end{aligned}
$$

where $\delta_{i j}=\frac{\partial u_{i}}{\partial x_{j}}+\frac{\partial u_{j}}{\partial x_{i}}, \mu_{e f f}=\mu_{t}+\mu$, and $\mu_{t}=C_{\mu} \frac{k^{2}}{\varepsilon}$. $R$ can be determined by:

$$
R=\frac{C_{\mu} \rho \eta^{3}\left(1-\frac{\eta}{\eta_{o}}\right)}{1+\beta \eta^{3}} \frac{\varepsilon^{2}}{k}
$$


Table 2. The meshing details of Haditha Kaplan turbine unit and Temenggor Francis turbine unit.

\begin{tabular}{|c|c|c|c|c|c|}
\hline Mesh details & & Nodes & Elements & Max. aspect ratio & $\begin{array}{c}\text { Minimum } \\
\text { orthogonal } \\
\text { quality }\end{array}$ \\
\hline \multicolumn{6}{|l|}{ Haditha Kaplan: } \\
\hline \multirow[t]{2}{*}{ Without weir } & Water & 9785833 & 2174630 & 10.706 & 0.23896 \\
\hline & Turbine & 1808946 & 401988 & 10.706 & 0.23896 \\
\hline \multirow[t]{2}{*}{ Weir height $=1.333 \mathrm{~m}$} & Water & 10371281 & 2304729 & 11.216 & 0.2315 \\
\hline & Turbine & 1835460 & 407880 & 11.216 & 0.2315 \\
\hline \multirow[t]{2}{*}{ Weir height $=2.667 \mathrm{~m}$} & Water & 10480064 & 2328903 & 12.012 & 0.2325 \\
\hline & Turbine & 1843668 & 409704 & 12.012 & 0.2325 \\
\hline \multirow[t]{2}{*}{ Weir height $=4 \mathrm{~m}$} & Water & 105932812 & 2354063 & 12.214 & 0.2385 \\
\hline & Turbine & 1844775 & 409950 & 12.214 & 0.2385 \\
\hline \multicolumn{6}{|l|}{ Temenggor Francis: } \\
\hline \multirow[t]{2}{*}{ Without weir } & Water & 97242978 & 2160955 & 14.561 & 0.17684 \\
\hline & Turbine & 2278165 & 506259 & 14.561 & 0.17684 \\
\hline \multirow[t]{2}{*}{ Weir height $=0.5 \mathrm{~m}$} & Water & 10092938 & 2242875 & 14.263 & 0.18043 \\
\hline & Turbine & 2276995 & 505999 & 14.263 & 0.18043 \\
\hline \multirow[t]{2}{*}{ Weir height $=1 \mathrm{~m}$} & Water & 10099465 & 2244325 & 14.202 & 0.18022 \\
\hline & Turbine & 2275416 & 505648 & 14.202 & 0.18022 \\
\hline \multirow[t]{2}{*}{ Weir height $=1.5 \mathrm{~m}$} & Water & 10137060 & 2252680 & 13.94 & 0.19626 \\
\hline & Turbine & 2277756 & 506168 & 13.94 & 0.19626 \\
\hline
\end{tabular}

where $\eta=S k / \varepsilon, \eta_{o}=4.38, C_{\mu}=0.0845, \beta=$ $0.012, C_{1 \varepsilon}=1.42$ "originally in the model procedure", $C_{2 \varepsilon}=1.68, \alpha_{k}=1.0$, and $\alpha_{\varepsilon}=0.769$. Among these constants used in the turbulence model, a properly chosen value of $C_{1 \varepsilon}$ is essential for improving the prediction of the pressure variation. In the present simulation, $C_{1 \varepsilon}=1.45$ was selected based on the preliminary computations.

\section{Description of hydraulic simulation}

It is essential to use the $k-\varepsilon$ turbulence model to describe the motion of turbulent flow through the turbine unit and, particularly, due to streamlines, to exhibit random motion near the turbine runner $[25,27,44]$. The $3 \mathrm{D}$ numerical model based on the finite volume method is used to distinguish the unsteady incompressible flow inside the turbine unit running under the varying head and discharge ranges and to solve the Reynoldsaveraged Navier-Stokes equations. All simulations were applied according to Computational Fluid Dynamic (CFD) approach. The hydraulic data (i.e., upstream and downstream water levels with discharge ranges) required to operate the model were collected from engineering reports that belong to the inspected case studies. Table 3 provides the hydraulic data of Haditha and Temenggor powerhouses, and specific speed (column 3) is calculated using Eqs. (4) and (5) during the first trial, respectively. Eq. (1) is used to calculate the hydraulic input power using the efficiency of the Haditha Kaplan and Temenggor Francis turbines with results of $71.1 \%$ and $83.4 \%$, respectively. 


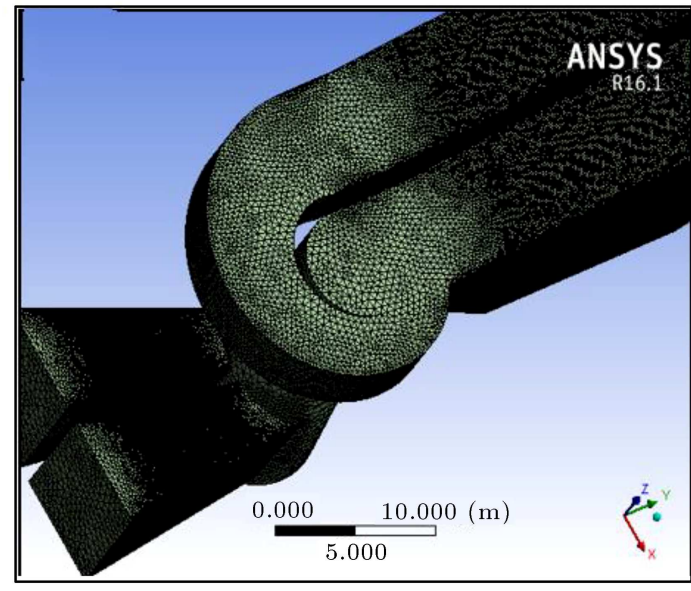

(a)

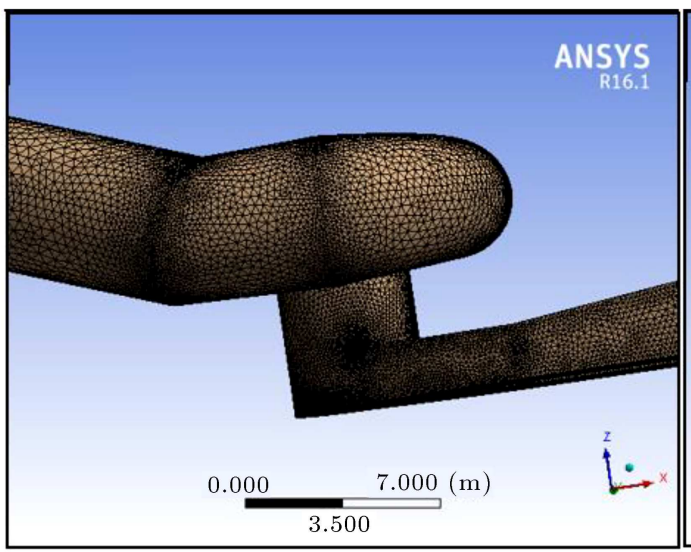

(c)

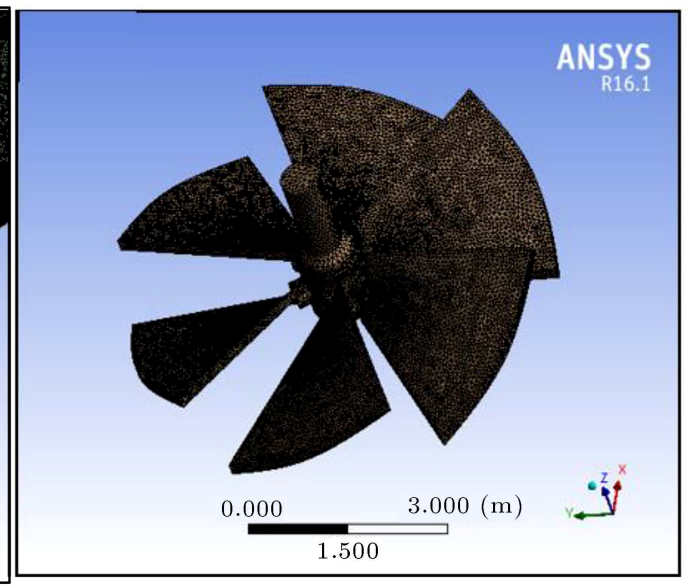

(b)

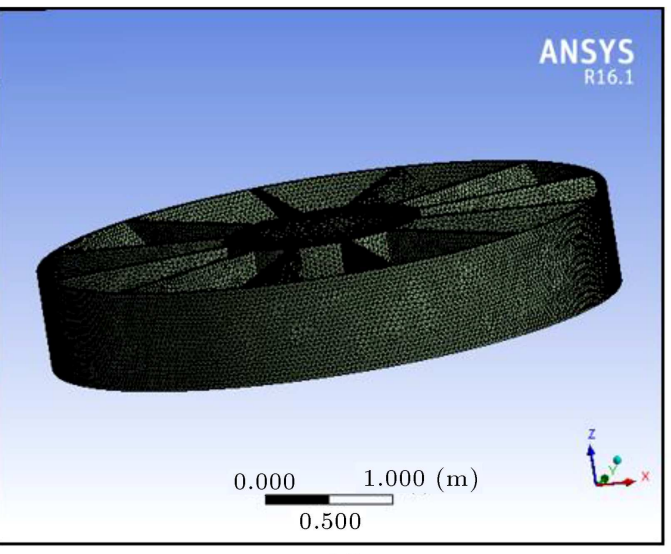

(d)

Figure 3. (a) 3D model of a vertical Kaplan unit with mesh details. (b) FE-Meshing of Haditha turbine runner model. (c) 3D model of vertical Francis unit with mesh details. (d) FE-Meshing of the Temenggor turbine runner model.

Table 3. Hydraulic calculations for Haditha turbine and Temenggor turbine units.

\begin{tabular}{cccccccc}
\hline No. & U/S.W. L $(\mathbf{m})$ & \multicolumn{1}{c}{ Net head $\mathbf{( m )}$} & $\mathbf{N}_{\boldsymbol{Q} E}$ & $\mathbf{Q}\left(\mathbf{m}^{3} / \mathbf{s}\right)$ & $\mathbf{P}(\mathbf{K W})$ & $\boldsymbol{V}_{\text {inlet }}(\mathbf{m} / \mathbf{s})$ & $\mathbf{N}(\mathbf{r a d} / \mathbf{s})$ \\
\hline $\mathbf{1}$ & 129 & 18.5 & 0.6779 & 100 & 25807 & 1.5038 & 3.3520 \\
$\mathbf{2}$ & 134.3 & 25.5 & 0.5800 & 118 & 41975 & 1.7744 & 3.3586 \\
$\mathbf{3}$ & 139.6 & 32.5 & 0.5155 & 136 & 61658 & 2.0451 & 3.3353 \\
$\mathbf{4}$ & 144.9 & 39.5 & 0.4689 & 151 & 83204 & 2.2707 & 3.3326 \\
$\mathbf{5}$ & 150.2 & 46.5 & 0.4331 & 169.5 & 109949 & 2.5489 & 3.2839 \\
\hline \multicolumn{7}{c}{ Hemenggor turbine } \\
\hline $\mathbf{1}$ & 236.5 & 94.50 & 0.2058 & 50.0 & 38658 & 2.1045 & 4.2671 \\
$\mathbf{2}$ & 239.48 & 97.48 & 0.2068 & 65.0 & 51840 & 2.7359 & 3.8491 \\
$\mathbf{3}$ & 242.46 & 100.46 & 0.2036 & 75.0 & 61644 & 3.1568 & 3.6091 \\
$\mathbf{4}$ & 245.44 & 103.44 & 0.2006 & 88.0 & 74474 & 3.7040 & 3.3551 \\
$\mathbf{5}$ & 248.42 & 106.42 & 0.1977 & 100.0 & 87068 & 4.2090 & 3.1687 \\
$\mathbf{1}$ & 236.5 & 94.50 & 0.2058 & 50.0 & 38658 & 2.1045 & 4.2671 \\
\hline
\end{tabular}

The inlet velocity calculated by applying the continuity equation and rotational speed are verified using Eq. (3). The Kaplan and Francis numerical 3D models were run by defining the gravity weight of water and the turbine components including the runner and the shaft as the submerged rotational bodies. The boundary conditions include inlet velocity (column 7 in Table 3 ), outlet pressure (1 atm), and the rotational speed of the turbine (column 8 in Table 3 ). The central axis turbine is defined as the rotational 
Table 4. Total head and percentage of error calculation at the inlets of the Haditha turbine unit and the Temenggor turbine unit.

\begin{tabular}{|c|c|c|c|c|c|c|c|c|c|}
\hline \multicolumn{10}{|c|}{ Haditha turbine } \\
\hline No. & $\begin{array}{c}\text { U/S.W. L } \\
(\mathbf{m})\end{array}$ & $\begin{array}{c}\mathrm{Q} \\
\left(\mathrm{m}^{3} / \mathrm{s}\right)\end{array}$ & $\begin{array}{l}V_{\text {inlet }} \\
(\mathrm{m} / \mathrm{s})\end{array}$ & $\begin{array}{c}P_{\text {inlet }} \\
(\mathbf{K P a})\end{array}$ & $\begin{array}{c}v^{2} / 2 g \\
(\mathrm{~m})\end{array}$ & $\begin{array}{l}p / \gamma \\
(\mathbf{m})\end{array}$ & $\begin{array}{c}\mathrm{Z} \\
(\mathrm{m})\end{array}$ & $H_{t}=v^{2} / 2 g+p / \gamma+Z$ & $\begin{array}{c}\text { Error } \\
(\%)\end{array}$ \\
\hline 1 & 129 & 100 & 1.504 & 232.61 & 0.115 & 23.71 & 105 & 129.08 & 0.06 \\
\hline 2 & 134.3 & 118 & 1.774 & 284.32 & 0.160 & 28.98 & 105 & 134.39 & 0.07 \\
\hline 3 & 139.6 & 136 & 2.045 & 338.15 & 0.213 & 34.47 & 105 & 139.93 & 0.24 \\
\hline 4 & 144.9 & 151 & 2.271 & 368.30 & 0.263 & 37.54 & 105 & 143.06 & 1.27 \\
\hline 5 & 150.2 & 169.5 & 2.549 & 469.50 & 0.331 & 47.86 & 105 & 153.44 & 2.16 \\
\hline \multicolumn{10}{|c|}{ Temenggor turbine } \\
\hline No. & $\begin{array}{c}\mathrm{U} / \mathrm{S} . \mathrm{W} \cdot \mathrm{L} \\
(\mathrm{m})\end{array}$ & $\begin{array}{c}\mathrm{Q} \\
\left(\mathrm{m}^{3} / \mathrm{s}\right)\end{array}$ & $\begin{array}{l}V_{\text {inlet }} \\
(\mathrm{m} / \mathrm{s})\end{array}$ & $\begin{array}{c}P_{\text {inlet }} \\
(\mathbf{K P a})\end{array}$ & $\begin{array}{c}v^{2} / 2 g \\
(\mathrm{~m})\end{array}$ & $\begin{array}{l}p / \gamma \\
(\mathbf{m})\end{array}$ & $\begin{array}{c}\mathrm{Z} \\
(\mathbf{m}) \\
\end{array}$ & $H_{t}=v^{2} / 2 g+p / \gamma+Z$ & $\begin{array}{c}\text { Error } \\
(\%)\end{array}$ \\
\hline 1 & 236.5 & 50 & 2.105 & 208.98 & 0.226 & 21.30 & 215 & 236.53 & 0.01 \\
\hline 2 & 239.48 & 65 & 2.736 & 236.04 & 0.382 & 24.06 & 215 & 239.44 & 0.02 \\
\hline 3 & 242.46 & 75 & 3.157 & 261.53 & 0.508 & 26.66 & 215 & 242.17 & 0.12 \\
\hline 4 & 245.44 & 88 & 3.704 & 293.85 & 0.699 & 29.95 & 215 & 245.65 & 0.08 \\
\hline 5 & 248.42 & 100 & 4.209 & 326.38 & 0.903 & 33.27 & 215 & 249.17 & 0.30 \\
\hline
\end{tabular}

axis, and the time step interval is 500 steps/0.01 s to show the rotational motion of the turbine around its axis [45]. The turbine models were runs several times by changing the rotational speeds of the turbine so that the pressure at the turbine inlets can be calculated; in doing so, the total head that is the summation of elevation head, velocity head, and pressure head, as tabulated in Table 4, is provided.

\section{Application and findings analysis}

As a matter of fact, turbines are usually designed locally in accordance with the dam conditions such as upstream and downstream water levels, water discharge, and various other hydraulic and hydrological factors. In addition, the efficiency of turbines is usually determined based on the off-design situation, especially in the case of the draft-tube turbine. Hence, there is a probability in its operation and reliability. Thus, it is necessary to maintain an optimal dimension of the individual components according to several properties (e.g., nature of flow and water level fluctuation). The motivation of this research is to optimize the draft-tube outlet by minimizing pressure fluctuation and fluent water velocity. Practically, two types of operating turbines, including Kaplan and Francis, were demonstrated as an example of the inspected application. According to Table 4, the calculation of the total head at the inlet of the Haditha and Temenggor turbine units is presented.

The phenomenon of fluid pattern is highly complex; thus, the advantage of Computational Fluid Dynamic (CFD) can be used to analyze fluid flow through the hydraulic mechanics concept. The CFD procedure is governed by dividing the fluid flow into finite volumes that can be solved numerically. In this work, the computational process was obtained by running the turbine models with different water levels, as shown in Table 3. The input rotational speed of a turbine is used, and several runs are performed to determine the inlet pressure that provides the total head at the inlet closest to the upstream water level.

In addition, Table 4 outlines the error percentage between the total head at the turbine inlet estimated by running the numerical models and the upstream water levels. The results showed that the error percentages between the total head estimated at the turbine model inlets and upstream water level of Haditha and Temenggor dams equal $2.16 \%$ and $0.3 \%$, respectively. The reason for this minor percentage of errors due to the head loss varies according to multiple forms of turbulent flow and the types of pipes (smooth or rough). In addition, the rotational speed of the turbine varies according to two variables (the head and discharge) obtained from the data source, where no clear relationship was found. The comparison of the 
total head at the turbine model inlets and the upstream water level indicates a practical procedure to find the accuracy of the model results.

Figure 4(a) shows the velocity distribution in Haditha turbine model with the maximum upstream water level $=150.2 \mathrm{~m}$ from the entrance up to the spiral casing; it varies due to changes in the cross-sectional area based on the continuity equation. Maximum velocities occur around the turbine runner because of the contraction of the cross-sectional area, and flow is limited to the lower part of the draft tube and the outlet based on the amount of water flow. Figure 4(b) illustrates a constant velocity distribution at the penstock of the Temenggor turbine model with the maximum upstream water level of $248.42 \mathrm{~m}$, because of the constant cross-sectional area. Velocity gradually increases from the spiral casing to the turbine runner because of the contraction of the cross-sectional area. Velocity is consistently distributed across the draft tube because of the rotational motion and the turbulent flow incident that occur following the running of the turbine. The results showed that the maximum water velocity occurred at the location of the turbine runner, namely $27.3 \mathrm{~ms}^{-1}$, for a discharge of $165.5 \mathrm{~m}^{3} \mathrm{~s}^{-1}$ in the Haditha turbine and $40 \mathrm{~ms}^{-1}$ for a discharge of $100 \mathrm{~m}^{3} \mathrm{~s}^{-1}$ in the Temenggor turbine. Although the discharge in the Haditha turbine is more than that in the Temenggor turbine, the cross-sectional area of the Haditha turbine is larger than that of the Temenggor turbine.

On the other hand, Figure 4(c) and (d) indicate the boundary pressure distributions in the Haditha and Temenggor turbine models, respectively. Here, the pressure distributions are proportional to the inverse of the velocity distribution based on the energy equation. The minimum pressure values are achieved following the running of the turbine; however, they do not reach cavitation pressure [46]. The velocity and pressure results obtained in the current study are in harmony with the modeling results accomplished by $[39,44,47]$.

Figure 5(a) and (b) display the wall shear stress distributions of the Haditha and Temenggor turbine units running under the maximum head, respectively. The maximum wall shear stress values are $0.56 \mathrm{kPa}$ and $1.5 \mathrm{kPa}$, which account for $0.1 \%$ and $0.25 \%$ of the maximum wall pressure values, respectively. Consequently, wall shear stress values are ignored in the process of transporting boundary pressure from the turbine models to the dam models for determining the effect of the running turbine on the dynamic behavior of the embankment dams, because their values are insignificant compared with the pressure values. Moreover, they depend on the pipe type (smooth or rough) and flow, which cannot be clearly identified.

Table 5 presents a comprehensively detailed visualization of the attained results on the pressure

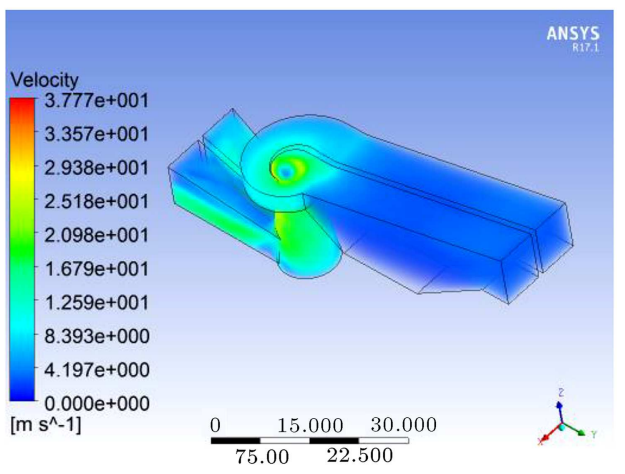

(a)

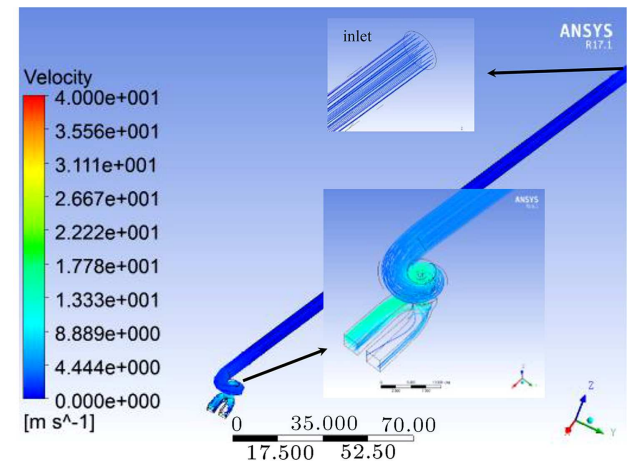

(b)

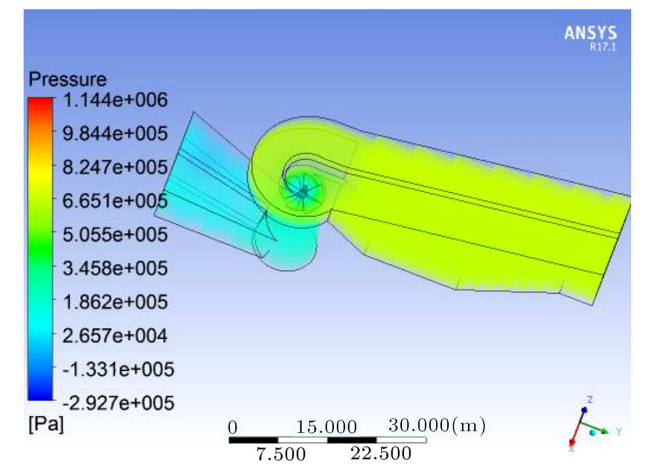

(c)

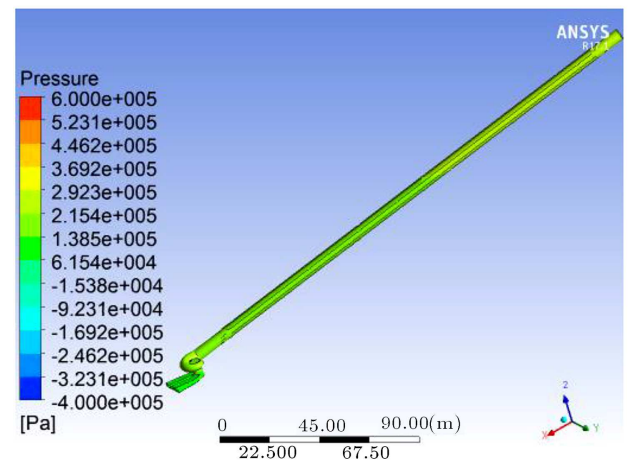

(d)

Figure 4. (a) Velocity vector of fluid in the flow passage at $t=4.80 \mathrm{~s}$ in Haditha turbine unit. (b) Velocity flow lines at $t=4.80 \mathrm{~s}$ in Temenggor turbine unit. (c) Pressure distribution of fluid in flow passage at $t=4.80 \mathrm{~s}$ in Haditha turbine unit. (d) Pressure distribution of fluid in flow passage at $t=4.80 \mathrm{~s}$ in Temenggor turbine unit. 


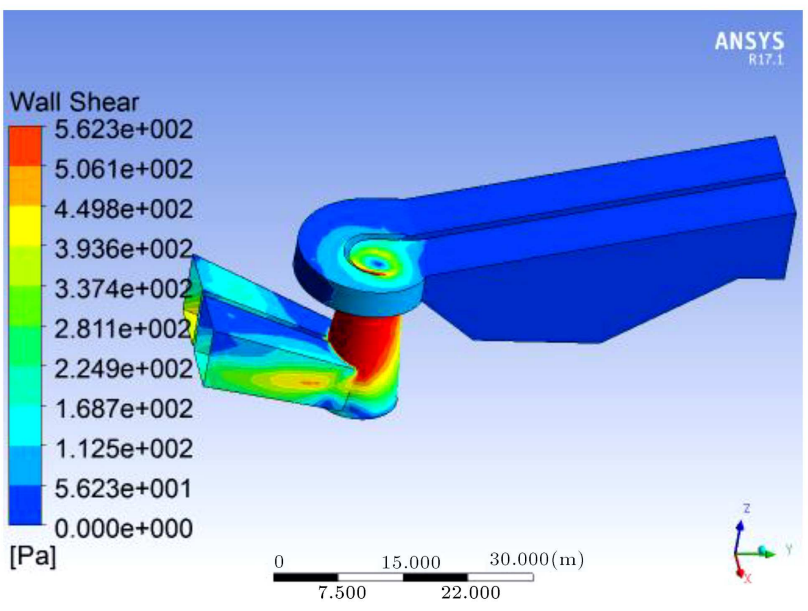

(a)

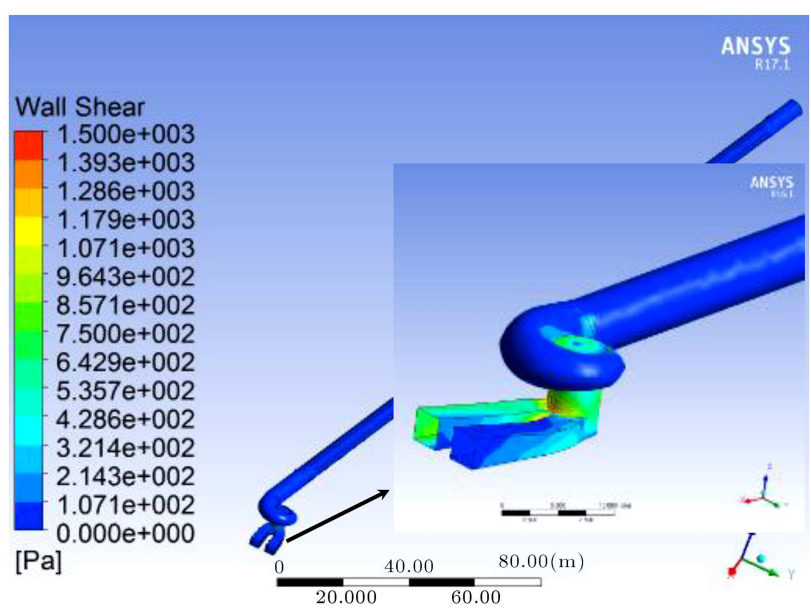

(b)

Figure 5. (a) Wall shear distribution of Haditha turbine unit. (b) Wall shear distribution of Temenggor turbine unit.

variation. The maximum differences in pressure above and below the turbine runner exist at the following heads, $144.9 \mathrm{~m}$ and $248.4 \mathrm{~m}$, for the Haditha and Temenggor turbine models, respectively, representing the best water level elevations to operate the turbines with the highest efficiency. Table 5 outlines the results of pressure fluctuation in both draft tubes (i.e., left and right). The attained results were determined based on running Haditha and Temenggor turbine models (i) without a weir as the first case and (ii) with three weir heights suggested as the second case. The results showed a reasonable depth of the submerged weir that represents $16.7 \%$ and $33.33 \%$ heights of the actual draft-tube opening for Haditha and Temenggor turbines. The optimal submerged weir heights determined for Haditha and Temenggor were $1.3 \mathrm{~m}$ and $1 \mathrm{~m}$, thus reducing the variation of the pressure.

In a more representable manner, the flow velocity (Figures 6 and 8) and flow pressure (Figures 7 and 9 ) on the left and right sides of draft tubes were displayed graphically for Haditha and Temenggor turbine models, respectively. In Figure 6, the flow velocity phenomenon of Haditha turbine was simulated in accordance with two different dam components at the upstream water level and submerged weir depth. Based on Figure 6, it can be recognized that the velocity distribution on both sides of the draft tube became more regular with an increase in the submerged weir height. The maximum velocity range located in the turbine runner region and affected by the running turbine at the minimum and maximum upstream water levels with different submerged weir heights varies $7.6 \%$ and $4.1 \%$, respectively. In terms of the water pressure value, Figure 7 indicates the water pressure fluctuation as well as pressure fluctuation in the dam's upstream water level and submerged weir depth. Based on the obtained results, building $1.333 \mathrm{~m}$ submerged weirs in the downstream of Haditha turbine units with the running turbine model at the minimum $(129 \mathrm{~m})$ and maximum upstream water levels $(150.2 \mathrm{~m})$ reduced the pressure difference range between left and right sides by $23 \%$ and $1 \%$ from the total head, respectively.

Further, Temenggor turbine was modeled to investigate the same two interesting measures of water velocity and pressure. Figure 8 presents the effect of the upstream water level and the proposed weir height to optimize suitable steady water flow. Based on the graphical visualization, the optimal velocity distribution was attained when a 1-m submerged weir was built in the downstream of the turbine outlet. The maximum velocity range located in the turbine running region and affected by the running turbine at the minimum $(236.5 \mathrm{~m})$ and maximum $(248.42 \mathrm{~m})$ upstream water levels with changing built submerged weir height varies $26.7 \%$ and $10.9 \%$, respectively. Water flow pressure is properly demonstrated in Figure 9. According to this figure, it can be concluded that running the turbine model at the minimum $(236.5 \mathrm{~m})$ and maximum upstream water levels $(248.42 \mathrm{~m}$ ) reduces the range of pressure differences between left and right sides by $8.5 \%$ and $15.9 \%$ from the total head, respectively.

From the engineering perspective, the cost of initiating a submerged weir is a very important element that needs to be considered by decision-makers. Note that constructing the submerged weir is not an easy task. It requires careful investigation, inspection, and optimized structure building. This might be costly in economic terms; yet, it is a great proposition for the dam sustainability and stability and hydropower operation.

In conclusion, results showed that a reduction in pressure fluctuation provides a uniform velocity distribution according to the Reynolds-averaged NavierStokes equations at the draft tubes, especially for the high discharge rates. This fluctuation is more visible in the Temenggor Francis turbine than in the Haditha 
Table 5. Draft-tube pressure results of different suggested weir heights in Haditha Kaplan turbine units and Temenggor Francis turbine unit.

\section{Haditha Kaplan turbine}

\begin{tabular}{|c|c|c|c|c|c|c|c|}
\hline \multicolumn{3}{|c|}{$\begin{array}{c}\text { The top surface of cone and draft } \\
\text { tube connection }\end{array}$} & \multicolumn{2}{|c|}{ Left side } & \multicolumn{2}{|c|}{ Right side } & \multirow{2}{*}{$\begin{array}{l}\text { Difference in } \\
\text { pressure head } \\
\text { between } \mathrm{L} \& \\
\mathrm{R} \text { sides }(\mathrm{m})\end{array}$} \\
\hline & $\mathrm{U} / \mathrm{S} . \mathrm{W} . \mathrm{L}(\mathrm{m})$ & Head (m) & $p(\mathbf{P a})$ & $p / \gamma(\mathbf{m})$ & $p(\mathrm{~Pa})$ & $p / \gamma(\mathbf{m})$ & \\
\hline \multirow[t]{3}{*}{ Without weir } & 150.2 & 46.5 & -37526 & -3.8253 & -18781 & -1.9145 & 1.9108 \\
\hline & 139.6 & 32.5 & -14033 & -1.4305 & -2298 & -0.2343 & 1.1962 \\
\hline & 129 & 18.5 & -5679 & -0.5789 & -699 & -0.0713 & 0.5076 \\
\hline \multirow[t]{3}{*}{ Weir height $=1.333 \mathrm{~m}^{*}$} & 150.2 & 46.5 & -12411 & -1.2651 & -5916 & -0.6031 & 0.6621 \\
\hline & 139.6 & 32.5 & -20255 & -2.0647 & -15899 & -1.6207 & 0.4440 \\
\hline & 129 & 18.5 & -5905 & -0.6019 & -6039 & -0.6156 & 0.0137 \\
\hline \multirow[t]{3}{*}{ Weir height $=2.667 \mathrm{~m}$} & 150.2 & 46.5 & 33013 & 3.36524 & -39305 & -4.0066 & 7.3719 \\
\hline & 139.6 & 32.5 & 11481 & 1.17034 & -23374 & -2.3827 & 3.5530 \\
\hline & 129 & 18.5 & -12293 & -1.2531 & -1850 & -0.1886 & 1.0645 \\
\hline \multirow[t]{3}{*}{ Weir height $=4 \mathrm{~m}$} & 150.2 & 46.5 & -42998 & -4.3831 & 60855 & 6.20336 & 10.5864 \\
\hline & 139.6 & 32.5 & -46978 & -4.7888 & 66184 & 6.74659 & 11.5354 \\
\hline & 129 & 18.5 & -22010 & -2.2436 & 35709 & 3.64006 & 5.8837 \\
\hline
\end{tabular}

Temenggor Francis turbine

\begin{tabular}{|c|c|c|c|c|c|c|c|}
\hline \multicolumn{3}{|c|}{$\begin{array}{c}\text { The top surface of cone and draft } \\
\text { tube connection }\end{array}$} & \multicolumn{2}{|c|}{ Left side } & \multicolumn{2}{|c|}{ Right side } & \multirow{2}{*}{$\begin{array}{c}\text { Difference in } \\
\text { pressure head } \\
\text { between } \mathrm{L} \& \\
\mathrm{R} \text { sides }(\mathrm{m})\end{array}$} \\
\hline & $\mathrm{U} / \mathrm{S} . \mathrm{W} . \mathrm{L}(\mathrm{m})$ & Head (m) & $p(\mathbf{P a})$ & $p / \gamma(\mathrm{m})$ & $p(\mathrm{~Pa})$ & $p / \gamma(\mathbf{m})$ & \\
\hline \multirow[t]{3}{*}{ Without weir } & 248.42 & 106.42 & -13295 & -13.553 & -26501 & -2.7014 & 10.8517 \\
\hline & 242.46 & 100.46 & -79352 & -8.0889 & -69172 & -7.0512 & 1.0377 \\
\hline & 236.5 & 94.5 & -34499 & -3.5167 & -2722 & -0.2775 & 3.2392 \\
\hline \multirow[t]{3}{*}{ Weir height $=0.5 \mathrm{~m}$} & 248.42 & 106.42 & -13195 & -13.451 & -30594 & -3.1187 & 10.3319 \\
\hline & 242.46 & 100.46 & -49423 & -5.038 & -14575 & -1.4857 & 3.5523 \\
\hline & 236.5 & 94.5 & -24250 & -2.472 & -7019 & -0.7155 & 1.7565 \\
\hline \multirow[t]{3}{*}{ Weir height $=1 \mathrm{~m}^{*}$} & 248.42 & 106.42 & -39805 & -4.0576 & -43601 & -4.4445 & 0.3869 \\
\hline & 242.46 & 100.46 & -22171 & -2.26 & -23700 & -2.4159 & 0.1559 \\
\hline & 236.5 & 94.5 & -12194 & -1.243 & -5728 & -0.5839 & 0.6591 \\
\hline \multirow[t]{3}{*}{ Weir height $=1.5 \mathrm{~m}$} & 248.42 & 106.42 & 56042 & 5.71274 & -21568 & -2.1986 & 7.9113 \\
\hline & 242.46 & 100.46 & 10345 & 1.05454 & -7566 & -0.7713 & 1.8258 \\
\hline & 236.5 & 94.5 & 2867 & 0.29225 & -1572 & -0.1602 & 0.4525 \\
\hline
\end{tabular}

\footnotetext{
*Indicate the optimal weir height.
} 


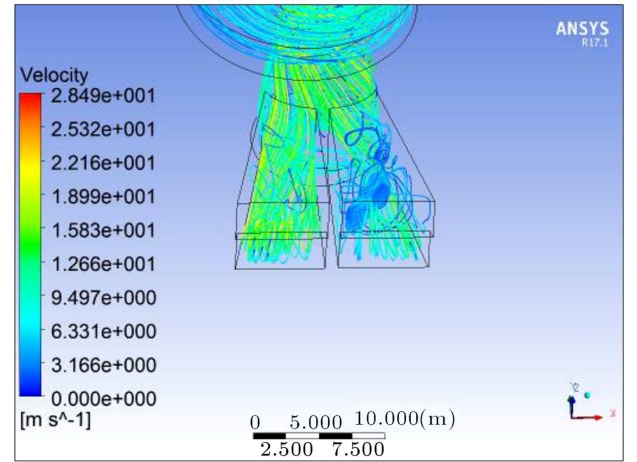

(a) Weir depth $=4 \mathrm{~m} \&$ U/S.W.L. $=129 \mathrm{~m}$

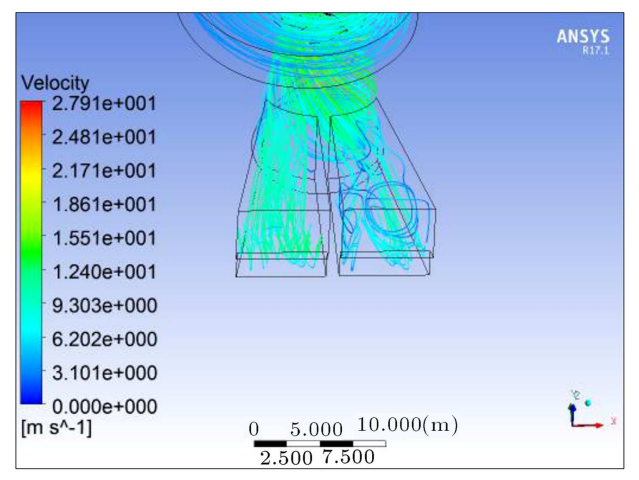

(c) Weir depth $=2.667 \mathrm{~m} \mathrm{\&} \mathrm{U/S.W.L.}=129 \mathrm{~m}$

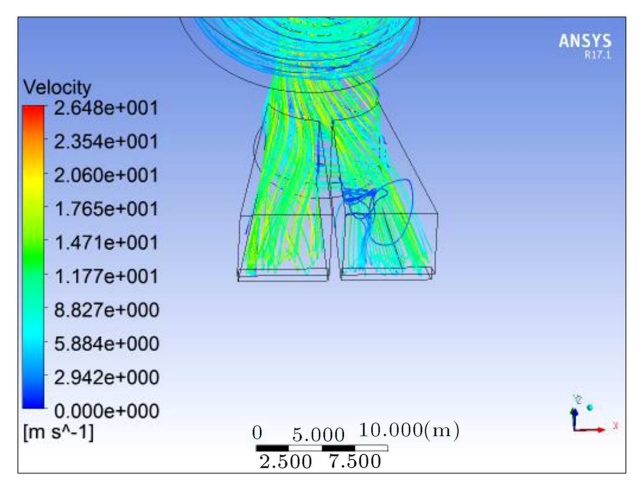

(e) Weir depth $=1.333 \mathrm{~m} \mathrm{\&} \mathrm{U/S.W.L.}=129 \mathrm{~m}$

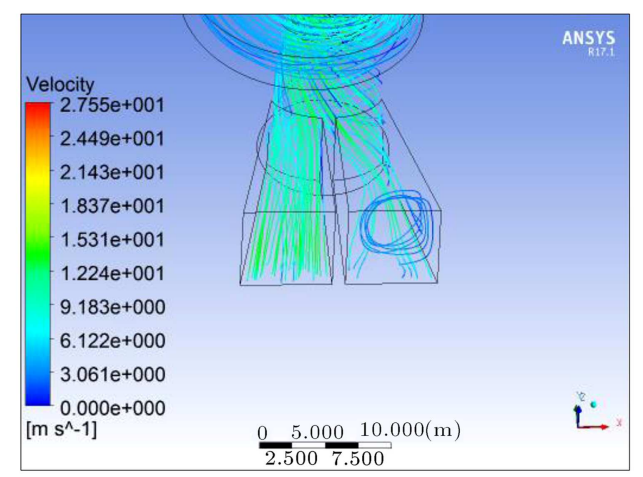

(g) Weir depth $=0 \mathrm{~m} \&$ U/S.W.L. $=129 \mathrm{~m}$

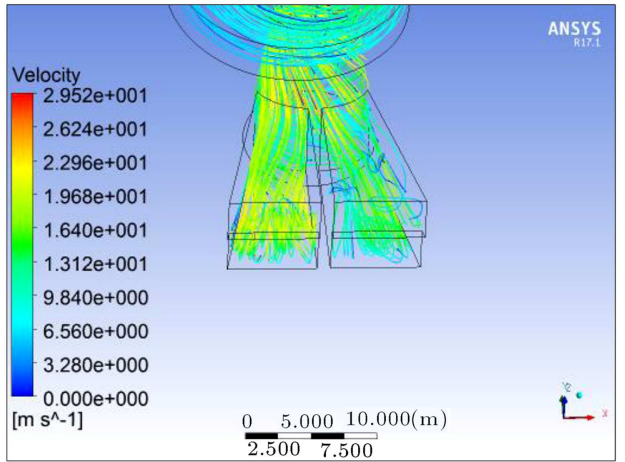

(b) Weir depth $=4 \mathrm{~m} \& \mathrm{U} /$ S.W.L. $=150.2 \mathrm{~m}$

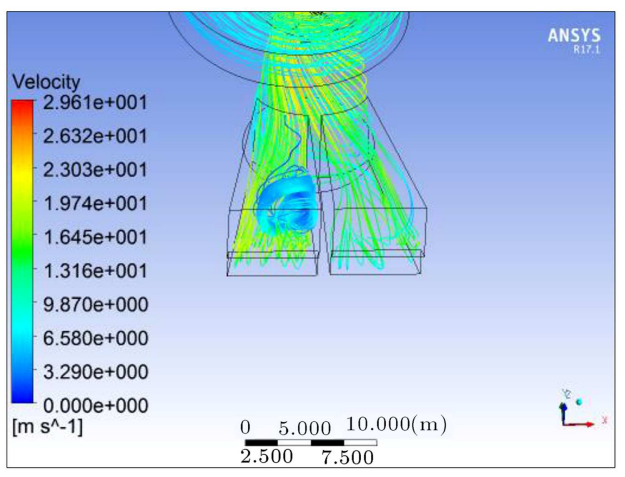

(d) Weir depth $=2.667 \mathrm{~m} \mathrm{\&} \mathrm{U} /$ S.W.L. $=150.2 \mathrm{~m}$

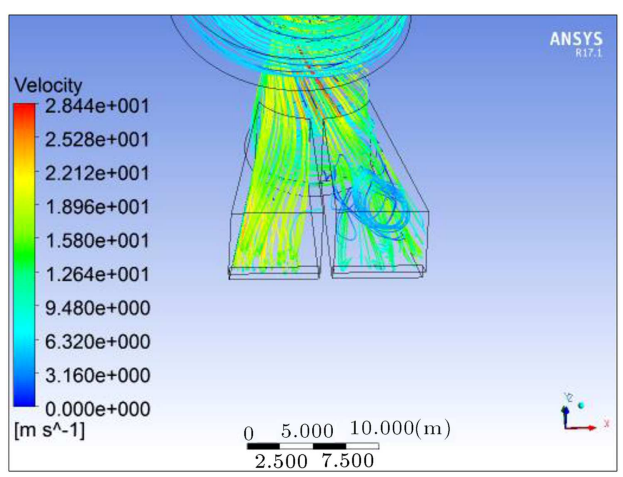

(f) Weir depth $=1.333 \mathrm{~m} \mathrm{\&} \mathrm{U/S.W.L.}=150.2 \mathrm{~m}$

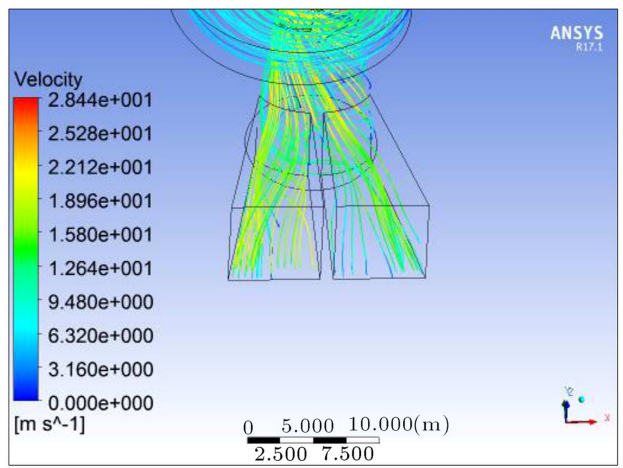

(h) Weir depth $=0 \mathrm{~m} \mathrm{\&} \mathrm{U/S.W.L.}=150.2 \mathrm{~m}$

Figure 6. Flow velocity magnitude in Haditha turbine unit. 


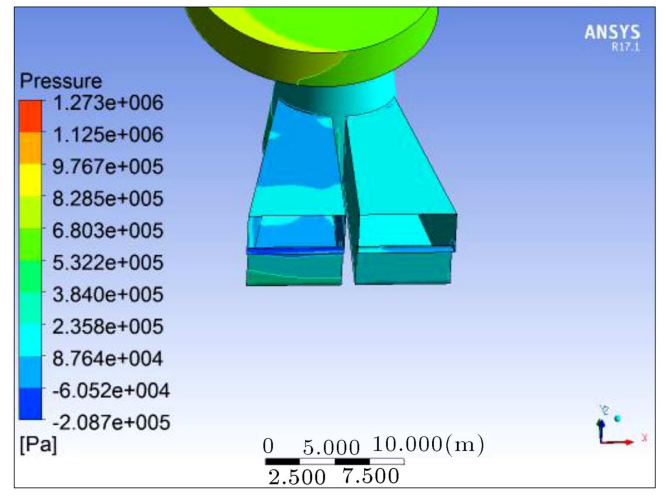

(a) Weir depth $=4 \mathrm{~m} \&$ U/S.W.L. $=129 \mathrm{~m}$

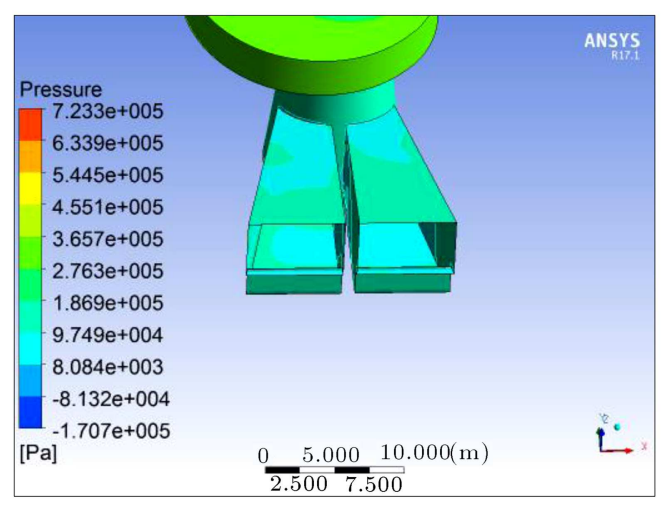

(c) Weir depth $=2.667 \mathrm{~m} \mathrm{\&} \mathrm{U} /$ S.W.L. $=129 \mathrm{~m}$

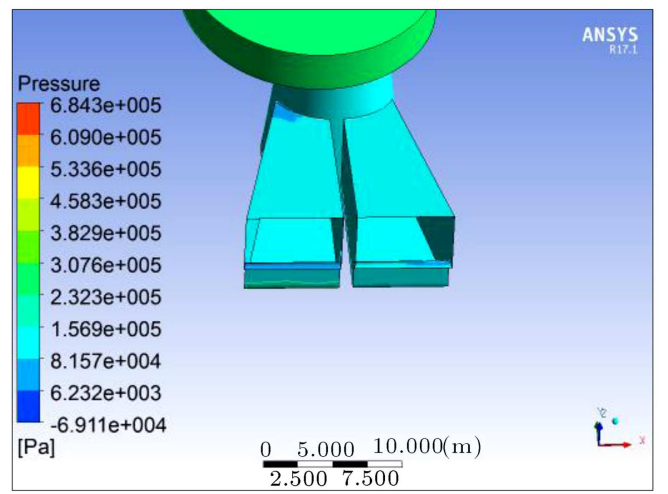

(e) Weir depth $=1.333 \mathrm{~m} \&$ U/S.W.L. $=129 \mathrm{~m}$

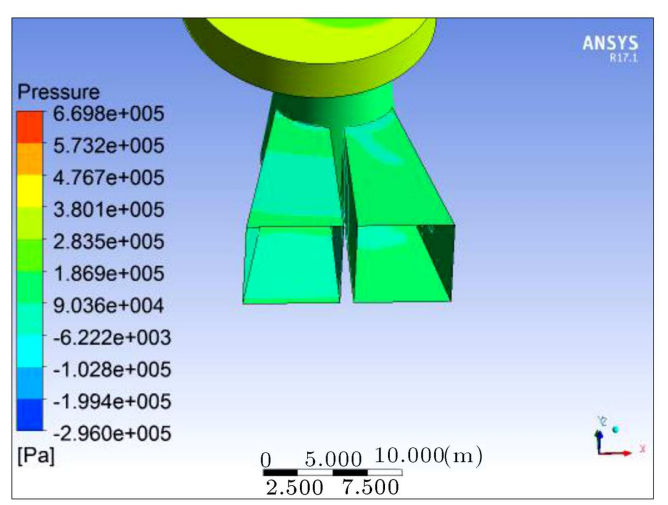

(g) Weir depth $=0 \mathrm{~m} \& \mathrm{U} /$ S.W.L. $=129 \mathrm{~m}$

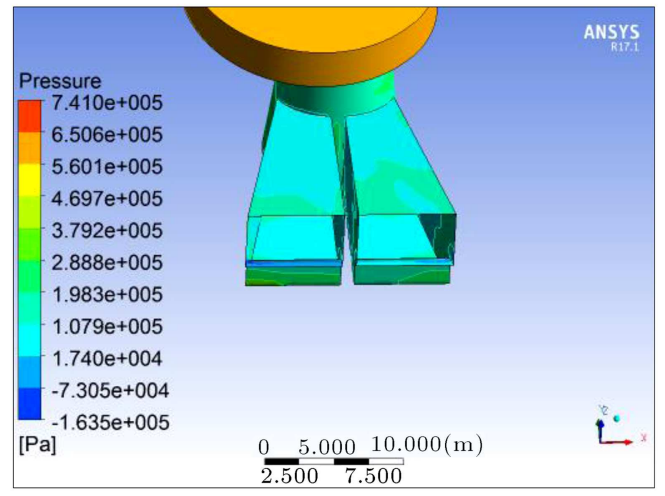

(b) Weir depth $=4 \mathrm{~m} \& \mathrm{U} /$ S.W.L. $=150.2 \mathrm{~m}$

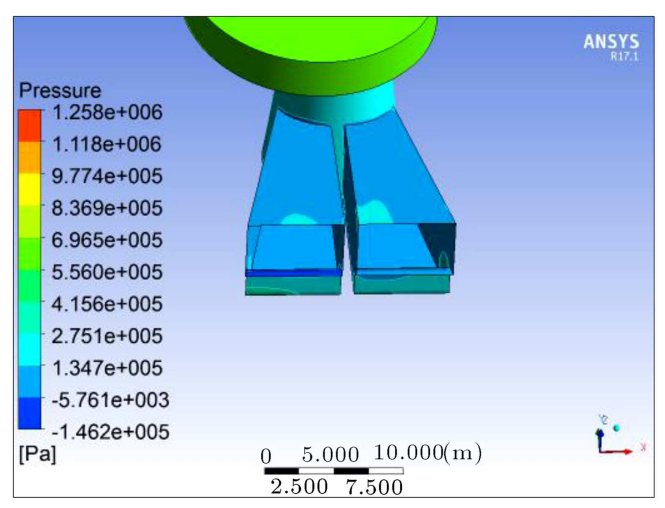

(d) Weir depth $=2.667 \mathrm{~m} \mathrm{\&} \mathrm{U} /$ S.W.L. $=150.2 \mathrm{~m}$

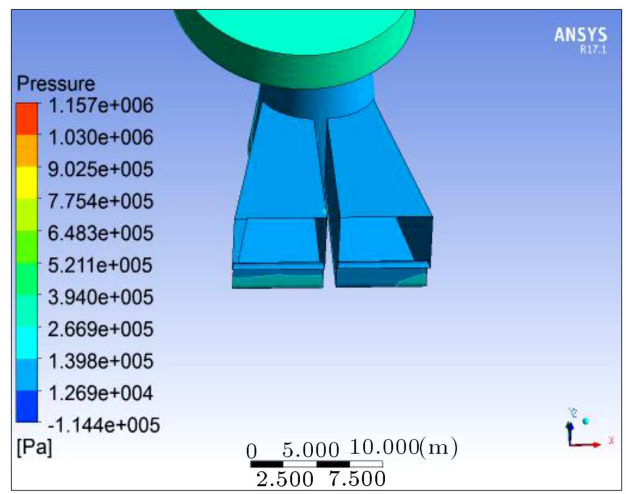

(f) Weir depth $=1.333 \mathrm{~m} \mathrm{\&} \mathrm{U} /$ S.W.L. $=150.2 \mathrm{~m}$

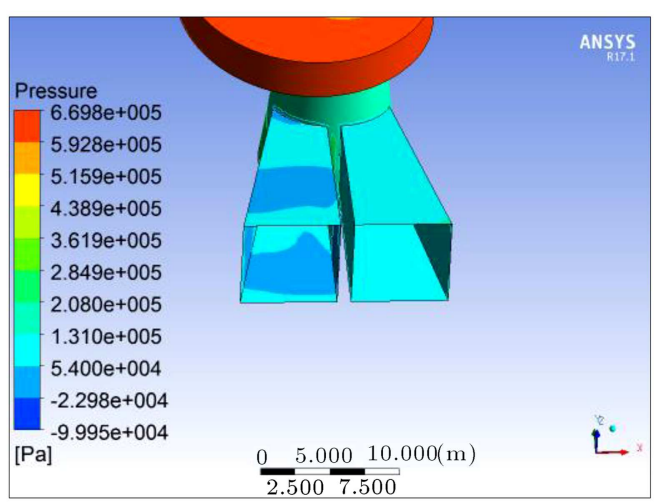

(h) Weir depth $=0 \mathrm{~m} \mathrm{\&} \mathrm{U/S.W.L.}=150.2 \mathrm{~m}$

Figure 7. Flow pressure magnitude in Haditha turbine unit. 


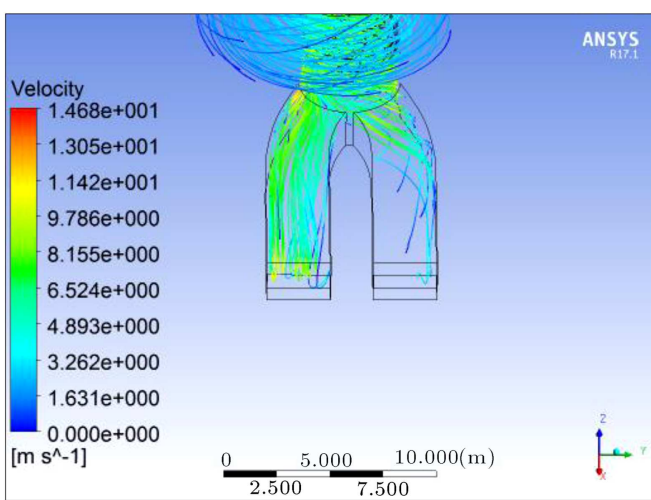

(a) Weir depth $=1.5 \mathrm{~m} \mathrm{\&} \mathrm{U/S.W.L.}=236.5 \mathrm{~m}$

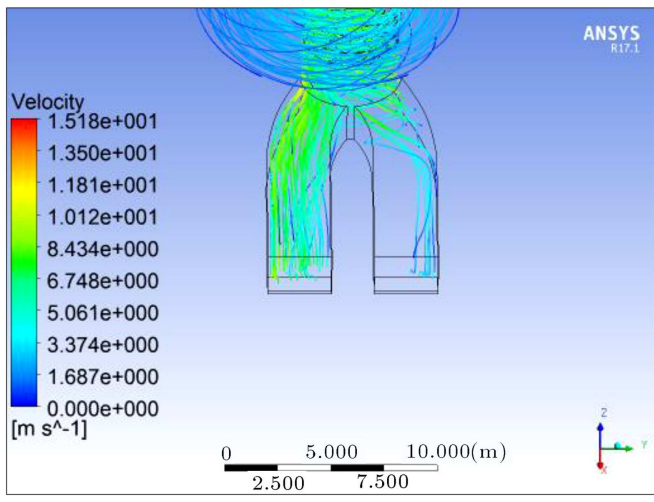

(c) Weir depth $=1 \mathrm{~m} \& \mathrm{U} /$ S.W.L. $=236.5 \mathrm{~m}$

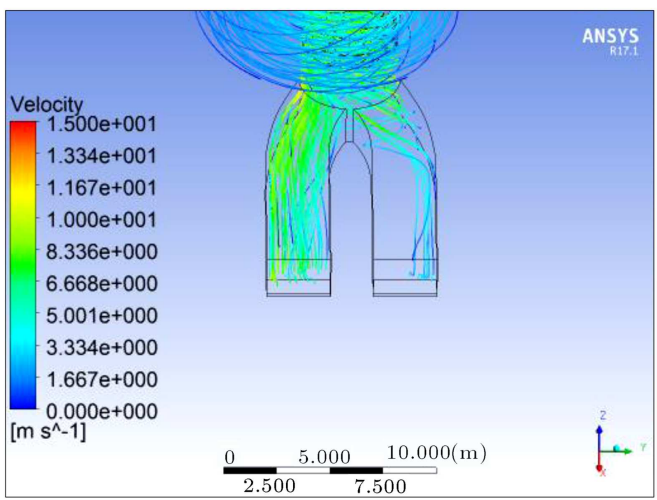

(e) Weir depth $=0.5 \mathrm{~m} \&$ U $/$ S.W.L. $=236.5 \mathrm{~m}$

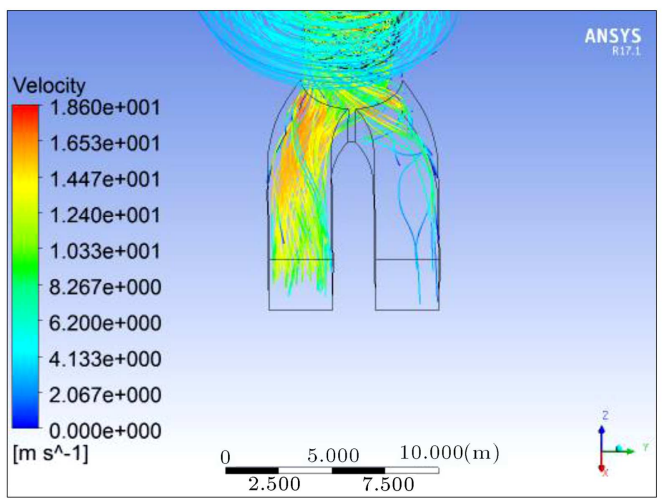

(g) Weir depth $=0 \mathrm{~m} \&$ U/S.W.L. $=236.5 \mathrm{~m}$

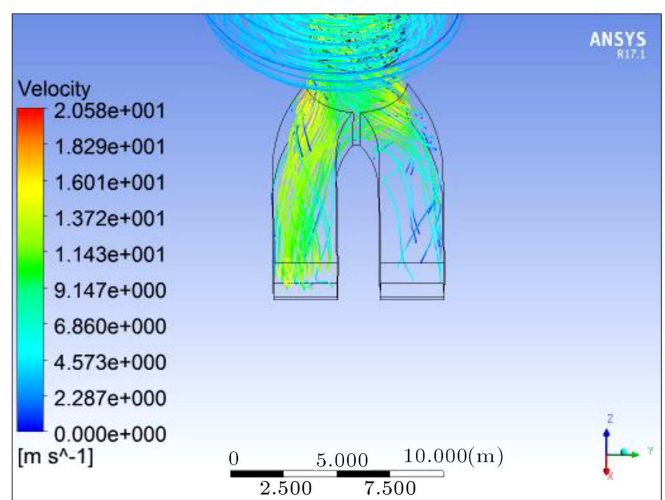

(b) Weir depth $=1.5 \mathrm{~m} \mathrm{\&} \mathrm{U/S.W.L.}=248.42 \mathrm{~m}$

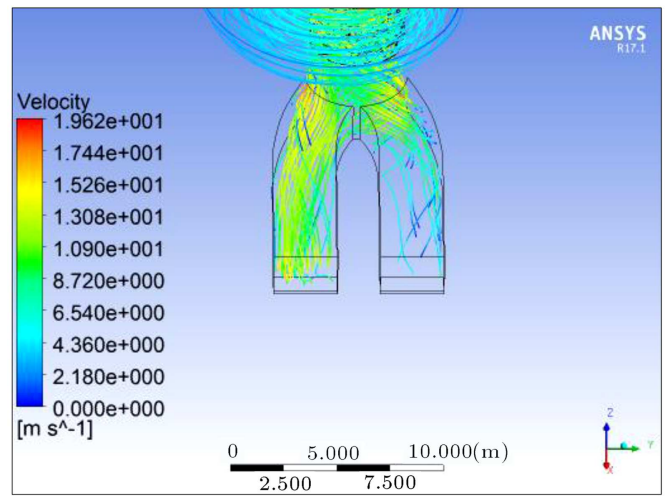

(d) Weir depth $=1 \mathrm{~m} \&$ U/S.W.L. $=248.42 \mathrm{~m}$

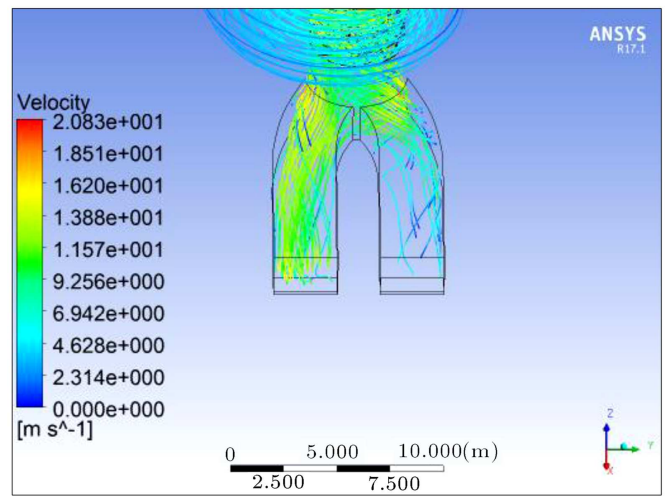

(f) Weir depth $=0.5 \mathrm{~m} \& \mathrm{U} / \mathrm{S}$. W.L. $=248.42 \mathrm{~m}$

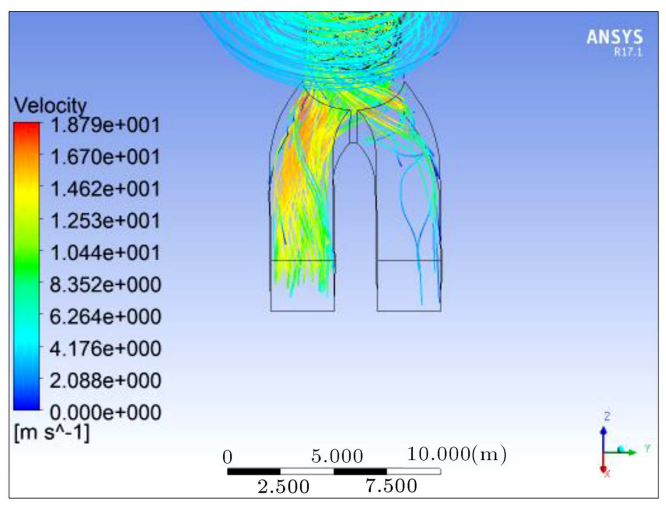

(h) Weir depth $=0 \mathrm{~m} \mathrm{\&} \mathrm{U/S.W.L.}=248.42 \mathrm{~m}$

Figure 8. Flow velocity magnitude in Temenggor turbine unit. 


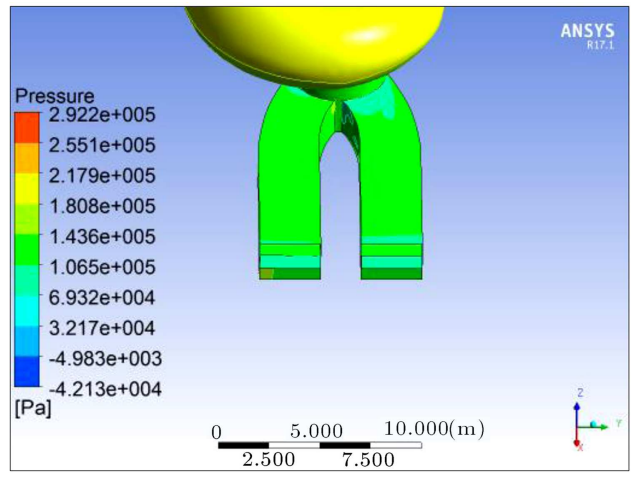

(a) Weir depth $=1.5 \mathrm{~m} \mathrm{\&} \mathrm{U} /$ S.W.L. $=236.5 \mathrm{~m}$

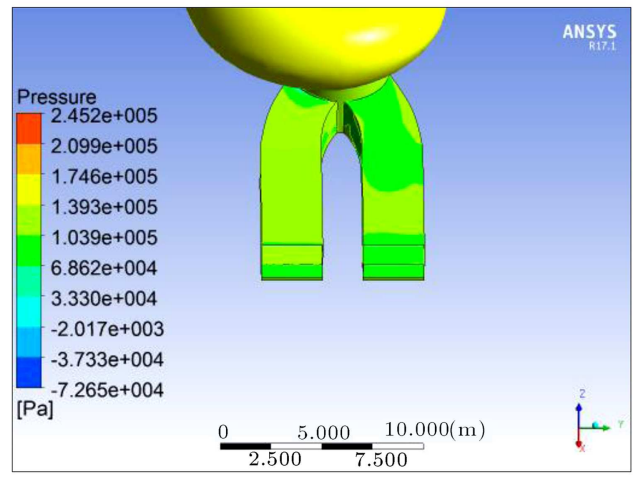

(c) Weir depth $=1 \mathrm{~m} \mathrm{\&} \mathrm{U} /$ S.W.L. $=236.5 \mathrm{~m}$

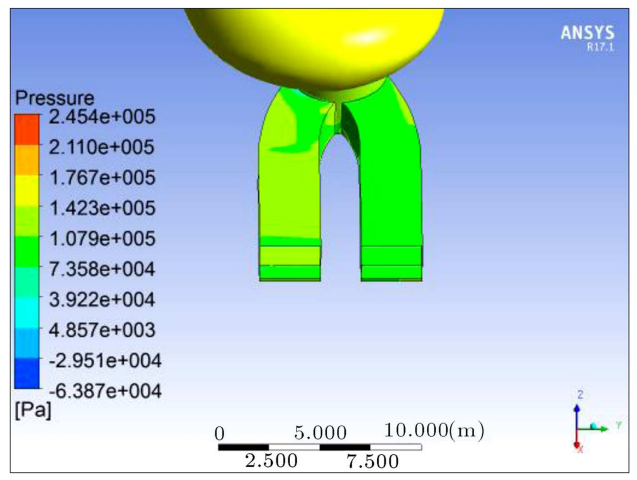

(e) Weir depth $=0.5 \mathrm{~m} \&$ U $/$ S.W.L. $=236.5 \mathrm{~m}$

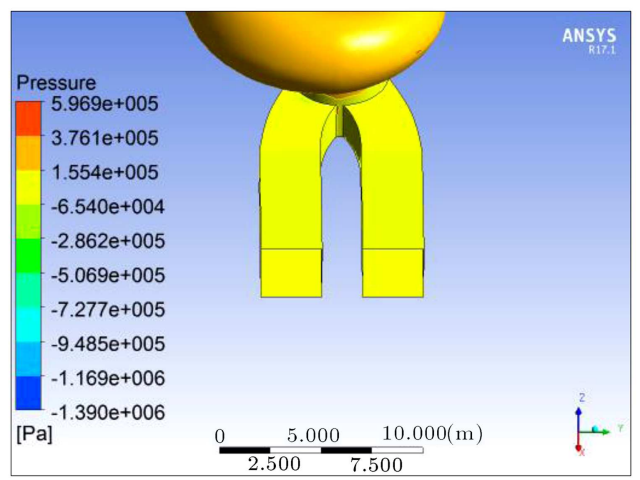

(g) Weir depth $=0 \mathrm{~m} \&$ U/S.W.L. $=236.5 \mathrm{~m}$

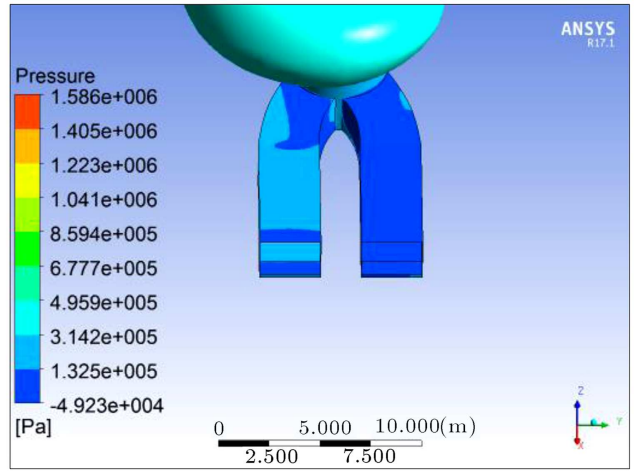

(b) Weir depth $=1.5 \mathrm{~m} \&$ U/S.W.L. $=248.42 \mathrm{~m}$

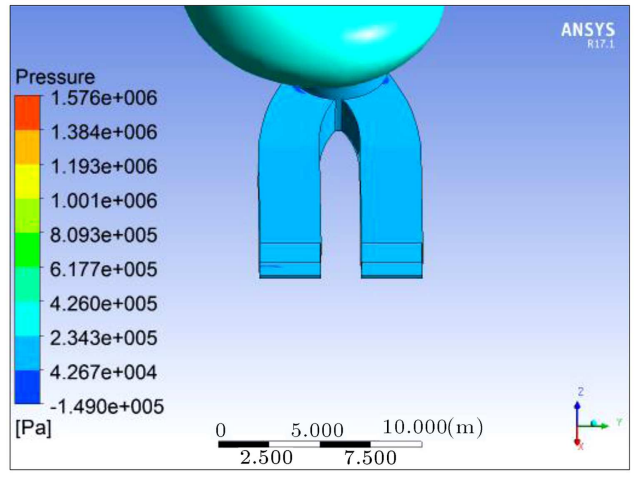

(d) Weir depth $=1 \mathrm{~m} \&$ U/S.W.L. $=248.42 \mathrm{~m}$

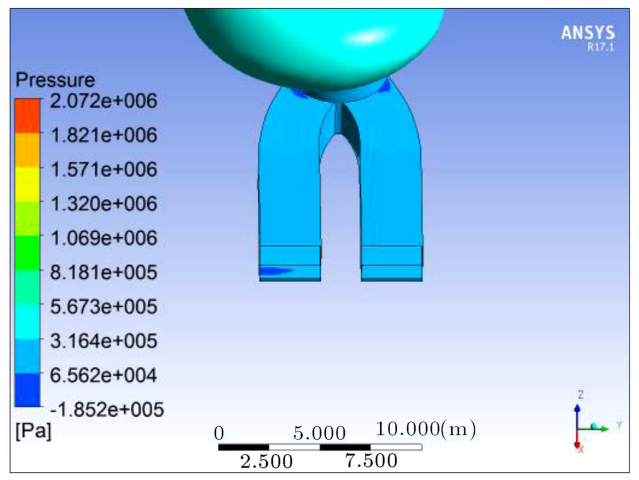

(f) Weir depth $=0.5 \mathrm{~m} \mathrm{\&} \mathrm{U/S.W.L.}=248.42 \mathrm{~m}$

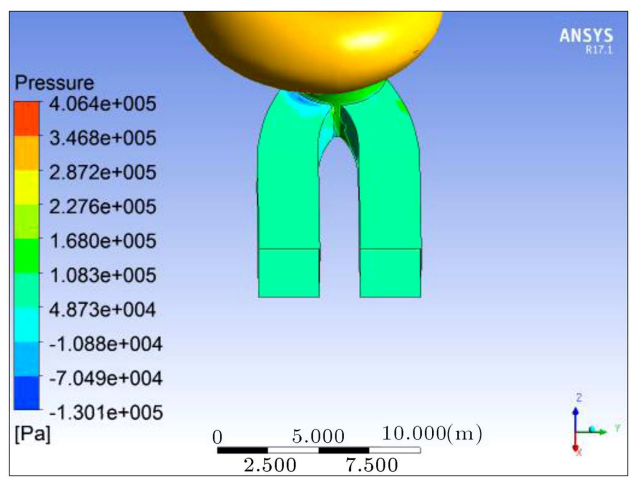

(h) Weir depth $=0 \mathrm{~m} \& \mathrm{U} /$ S.W.L. $=248.42 \mathrm{~m}$

Figure 9. Flow pressure magnitude in Temenggor turbine unit. 
Kaplan turbine due to the operation under high water level of the upstream (Table 1). The recommended submerged weir construction at the outlet draft tube results from the uneven distribution of water flow, particularly in the diffuser section. The findings indicate an essential solution that can be implemented practically in the powerhouse system operation in order to maintain a steady draft-tube water flow with balanced water pressures on both sides of the outlet. The proposed submerged weir can be further extended to envisage the instabilities of turbine outlet components of the prototype off-design operation.

\section{Conclusions}

A draft tube is an essential component of the powerhouse system that is located in the downstream part of any type of reaction turbines. The main goal of this draft tube is to convert the high-impact kinetic energy at the turbine runner outlet into pressure energy gradually. However, the off-design of draft tube initiates turbulent and fluctuating pressures during online operation; hence, solving this problem is extremely significant for the sustainability of dam body. This research provides a detailed analysis of the characteristics of the vertical Kaplan and Francis turbines influenced by changing water levels and discharge ranges. The actual pressure of the water flowing through the draft tube was computed qualitatively and presented numerically to verify the operation and performance of the turbines. The main determined pressures were obtained based on the proposition of a regulated submerged weir with different depths. The pressure distribution of unsteady flow was predicted through time-dependent running turbines. The change in the upstream water level head provides a guideline for flow characteristics in the turbine units. An increase in head per unit discharge is the main guideline for generating hydroelectric power. The construction of the power station far from the dam body increases the length of the waterway, leading to increased energy loss. However, a dam is protected from powerhouse vibration. The results of the proposed constructed submerged weir showed a very reasonable and reliable draft-tube turbine operation with very regular pressures. The Kaplan draft-tube turbine fits $1.33 \mathrm{~m}$ submerged weir height that comprises $16.7 \%$ of the total opening. On the other hand, the Francis draft-tube turbine was designed optimally with a 1$\mathrm{m}$ submerged weir height that represents $33.3 \%$ of the total tube open depth. The intended suggestion was very sufficient and feasible for minimizing pressure fluctuation on both sides of the draft tubes of the investigated case studies. This research can be further extended to inspect the role of stressed components in the draft tube walls and propose a systematic hydropower operation based on the computed stresses.

\section{References}

1. Pennacchi, P., Borghesani, P., and Chatterton, S. "A cyclostationary multi-domain analysis of fluid instability in Kaplan turbines", Mech. Syst. Signal Process, 60, pp. 375-390 (2015).

2. Kumar, P., Saini, R.P., Study of Cavitation in Hydro Turbines-A Review (2010)

3. Dixon, S.L. and Hall, C.A. "Hydraulic turbines", In: Chapter 9, Fluid Mechanics and Thermodynamics of Turbomachinery, pp. 361-418 (2014).

4. Grassmann, H. and Ganis, M.L. "On partially static Kaplan turbines", Renew. Energy, 30, pp. 179-186 (2005).

5. Luo, H.P. and Al-Dahhan, M.H. "Verification and validation of CFD simulations for local flow dynamics in a draft tube airlift bioreactor", Chem. Eng. Sci., 66, pp. 907-923 (2011).

6. Fu, T., Deng, Z.D., Duncan, J.P., Zhou, D., Carlson, T.J., Johnson, G.E., and Hou, H. "Assessing hydraulic conditions through Francis turbines using an autonomous sensor device", Renew. Energy, 99, pp. 1244-1252 (2016).

7. Glatzel, T., Litterst, C., Cupelli, C., Lindemann, T., Moosmann, C., Niekrawietz, R., Streule, W., Zengerle, R., and Koltay, P. "Computational fluid dynamics (CFD) software tools for microfluidic applications - A case study", Comput. Fluids, 37, pp. 218-235 (2008).

8. Wang, Z.J. "High-order computational fluid dynamics tools for aircraft design", Philos. Trans. A. Math. Phys. Eng., Sci., 372, p. 20130318 (2014).

9. Lomax, H., Pulliam, T., Zingg, D., and Kowalewski, T. "Fundamentals of computational fluid dynamics", Appl. Mech. Rev., 55, p. B61 (2002).

10. Thapa, B.S., Thapa, B., and Dahlhaug, O.G. "Empirical modelling of sediment erosion in Francis turbines", Energy, 41, pp. 386-391 (2012).

11. Stein, P., Sick, M., Dörfler, P., White, P., and Braune, A. "Numerical simulation of the cavitating draft tube vortex in a Francis turbine", In: 23rd IAHR Symposium on Hydraulic Machinery and Systems, October $17-21$, p. 4711 (2006)

12. Iliescu, M.S., Ciocan, G.D., and Avellan, F. "Analysis of the cavitating draft tube vortex in a Francis turbine using particle image velocimetry measurements in twophase flow", J. Fluids Eng., 130, p. 21105 (2008).

13. Jošt, D. and Lipej, A. "Numerical prediction of noncavitating and cavitating vortex rope in a Francis turbine draft tube", Stroj Vestnik/Journal Mech. Eng., 57, pp. 445-456 (2011).

14. Zhang, H. and Zhang, L. "Numerical simulation of cavitating turbulent flow in a high head Francis turbine at part load operation with OpenFOAM", Procedia Eng., 31, pp. 156-165 (2012).

15. Qian, Z.D., Yang, J.D., and Huai, W.X. "Numerical simulation and analysis of pressure pulsation in Francis hydraulic turbine with air admission", Journal of Hydrodynamics, Ser. B, $19(4)$, pp. 467-472 (2007). 
16. Anup, K.C., Thapa, B., and Lee, Y.H. "Transient numerical analysis of rotor-stator interaction in a Francis turbine", Renew. Energy, 65, pp. 227-235 (2014).

17. Luna-Ramírez, A., Campos-Amezcua, A., DorantesGómez, O., Mazur-Czerwiec, Z., and Muñoz-Quezada, R. "Failure analysis of runner blades in a Francis hydraulic turbine - Case study", Eng. Fail. Anal, 59, pp. 314-325 (2016).

18. Landry, C., Favrel, A., Müller, A., Nicolet, C., and Avellan, F. "Local wave speed and bulk flow viscosity in Francis turbines at part load operation", J. Hydraul. Res., 54, pp. 185-196 (2016).

19. Trivedi, C., Cervantes, M.J., Gandhi, B.K., and Dahlhaug, O.G. "Experimental and numerical studies for a high head Francis turbine at several operating points", J. Fluids Eng., 135, p. 111102 (2013).

20. Gebreslassie, M.G., Tabor, G.R., and Belmont, M.R. "Numerical simulation of a new type of cross flow tidal turbine using OpenFOAM - Part II: Investigation of turbine-to-turbine interaction", Renew. Energy, 50, pp. 1005-1013 (2013).

21. Negru, R., Muntean, S., Marsavina, L., Susan-Resiga, R., and Pasca, N. "Computation of stress distribution in a Francis turbine runner induced by fluid flow", In: Computational Materials Science, pp. 253-259 (2012)

22. Minakov, A.V., Platonov, D.V., Dekterev, A.A., Sentyabov, A.V., and Zakharov, A.V. "The numerical simulation of low frequency pressure pulsations in the high-head Francis turbine", Comput. Fluids, 111, pp. 197-205 (2015).

23. Trivedi, C., Cervantes, M.J., and Gunnar Dahlhaug, O. "Numerical techniques applied to hydraulic turbines: A perspective review", Appl. Mech. Rev., 68, p. 10802 (2016). DOI: 10.1115/1.4032681

24. Ko, P. and Kurosawa, S. "Numerical simulation of turbulence flow in a Kaplan turbine -Evaluation on turbine performance prediction accuracy", IOP Conf. Ser. Earth Environ. Sci., 22, pp. 1-10 (2014).

25. Javadi, A. and Nilsson, H. "Unsteady numerical simulation of the flow in the U9 Kaplan turbine model", 27th IAHR Symp. Hydraul. Mach. Syst, 22, pp. 1-9 (2014).

26. Favrel, A., Müller, A., Landry, C., Yamamoto, K., and Avellan, F. "Study of the vortex-induced pressure excitation source in a Francis turbine draft tube by particle image velocimetry", Exp. Fluids, 56, pp. 1-15 (2015).

27. Mo, Z., Xiao, J., and Wang, G. "Numerical research on flow characteristics around a hydraulic turbine runner at small opening of cylindrical valve", Math. Probl. Eng., 2016, Article ID: 6951839, 8 pages (2016).

28. Hou, C. "Three-dimensional numerical analysis of flow pattern in pressure forebay of hydropower station", Procedia Eng., 28, pp. 128-135 (2012).

29. Hager, W. and Schwalt, M. "Broad-crested weir", J. Irrig. Drain. Eng., 120, pp. 13-26 (1994).
30. Gonzalez, C.A. and Chanson, H. "Experimental measurements of velocity and pressure distributions on a large broad-crested weir", Flow Meas. Instrum, 18, pp. 107-113 (2007).

31. Khassaf, S.I., Abeed, K.R., and Saleh, L.A.M. "Predicting the breach hydrograph resulting due to hypothetical failure of Haditha Dam", Jordan J. Civ. Eng., 5, pp. 392-400 (2011).

32. Yong Ooi Lin, C. "Autonomy re-constituted: Social and gendered implications of dam resettlement on the Orang Asli of Peninsular Malaysia", Gend. Technol. Dev., 10, pp. 77-99 (2006).

33. Vilanova, M.R.N. and Balestieri, J.A.P. "Modeling of hydraulic and energy efficiency indicators for water supply systems", Renew. Sustain. Energy Rev., 48, pp. 540-557 (2015).

34. Samora, I., Hasmatuchi, V., Mnch-Allign, C., Franca, M.J., Schleiss, A.J., and Ramos, H.M. "Experimental characterization of a five blade tubular propeller turbine for pipe inline installation", Renew. Energy, 95, pp. 356-366 (2016).

35. Li, Q.F., Quan, H., Li, R.N., and Jiang, D.J. "Influences of guide vanes airfoil on hydraulic turbine runner performance", In: Procedia Engineering, pp. 703-708 (2012).

36. Iryo, T. and Rowe, R.K. "On the hydraulic behavior of unsaturated nonwoven geotextiles", Geotext. Geomembranes, 21, pp. 381-404 (2003).

37. Feintuch, P. "The international electrotechnical vocabulary of the international electrotechnical commission", Meta, 34, pp. 539-541 (1989).

38. Becker, D. "Harmonizing the international electrotechnical commission common information model (CIM) and 61850", Electr. Power Res. Inst. (EPRI), Tech. Rep., 1020098 (2010).

39. Muis, A., Sutikno, P., Soewono, A., and Hartono, F. "Design optimization of axial hydraulic turbine for very low head application", In: Energy Procedia, 68, pp. 263-273 (2015).

40. Slootweg, J.G., de Haan, S.W.H., Polinder, H., and Kling, W.L. "General model for representing variable speed wind turbines in power system dynamics simulations", IEEE Trans. Power Syst., 18, pp. 144-151 (2003).

41. Heckelsmueller, G.P. "Application of variable speed operation on Francis turbines", Ing. e Investig, 35, pp. 12-16 (2015).

42. Liu, S., Li, S., and Wu, Y. "Pressure fluctuation prediction of a model Kaplan turbine by unsteady turbulent flow simulation", J. Fluids Eng., 131, p. 101102 (2009).

43. Li, J., Yu, J., and Wu, Y. "3D unsteady turbulent simulations of transients of the Francis turbine", In: IOP Conference Series: Earth and Environmental Science, p. 12001, IOP Publishing (2010). 
44. Zhang, H. and Zhang, L. "Numerical simulation of cavitating turbulent flow in a high head Francis turbine at part load operation with OpenFOAM", Procedia Eng., 31, pp. 156-165 (2012).

45. Wei, S. and Zhang, L. "Vibration analysis of hydropower house based on fluid-structure coupling numerical method", Water Sci. Eng., 3, pp. 75-84 (2010).

46. Caupin, F. and Herbert, E. "Cavitation in water: A review", Comptes Rendus Physique, 7(9-10), pp. 1000-1017 (2006).

47. Wei, S. and Zhang, L. "Vibration analysis of hydropower house based on fluid-structure coupling numerical method", Water Sci. Eng., 3, pp. 75-84 (2010).

\section{Biographies}

Ameen Mohammed Salih Ameen is currently a PhD candidate at University of Malaya and an Assistance Lecturer at the Water Resources Engineering Department, Faculty of Engineering, University of Baghdad. He obtained his BSc degree in Irrigation and Drainage Engineering and MSc in Hydraulic Engineering from the University of Baghdad, Iraq. His field of specialization is water resources, hydraulics, and hydraulic structures. He has authored and coauthored technical papers and reports in national and international publications and has served as a referee for papers published in local and international journals.

Zainah Ibrahim received her BSc degree in Civil Engineering, 1990, Middlesex Polytechnic, UK, MSc degree in Structural Engineering, 1994, University of Liverpool, UK, and PhD degree in Structural Engineering, 2007, University of Sheffield, UK. She joined the University of Malaya, Malaysia, as a Lecturer in 1995, where she is currently an Associate Professor at the Department of Civil Engineering. She is the author or co-author of 50 peer-refereed articles, and her research interests include structural health monitoring and system identification of civil structures, FEM, composite materials \& structures, damage detection, and rehabilitation of structures.

Faridah Othman is currently a lecturer at the Civil Engineering Department, Faculty of Engineering, University of Malaya. She obtained her BSc degree in Civil Engineering from the University of Missouri Kansas City, USA and MSc and PhD degrees from the University of Newcastle Upon Tyne, UK. Her fields of specialization are water resources, environmental hydraulics, river and water quality modeling, water distribution, and sewerage network. She has been involved in modeling exercise for almost 20 years and is actively involved in the study of the water resources management, river, and surface water quality studies, performance, and quality of water supply, sewerage network, flood mitigation works, and GIS application in Water Engineering. Dr. Faridah has supervised a number of PhDs, Masters, and undergraduates students in their final-year theses. She has authored and co-authored several technical papers and reports in national and international publications, and she has served as a referee for papers published in local and international journals.

Zaher Mundher Yaseen is a senior lecturer and senior researcher in the field of Civil Engineering. He has established his master and doctorate degrees between 2012-2017 at the National University of Malaysia (UKM), Malaysia. Dr. Yaseen is major in hydrology, water resources engineering, hydrological processes modeling, environmental engineering and climate. In addition, he has an excellent expertise in machine learning and advanced data analytics. He has published over 100 articles in international journals with a Google Scholar H-Index of 21, and a total of 1404 citations. 